\title{
Extrachromosomal Elements as Possible Agents of Adaptation and Development
}

\author{
DARRYL REANNEY \\ Department of Biochemistry, Lincoln College, Canterbury, New Zealand
}

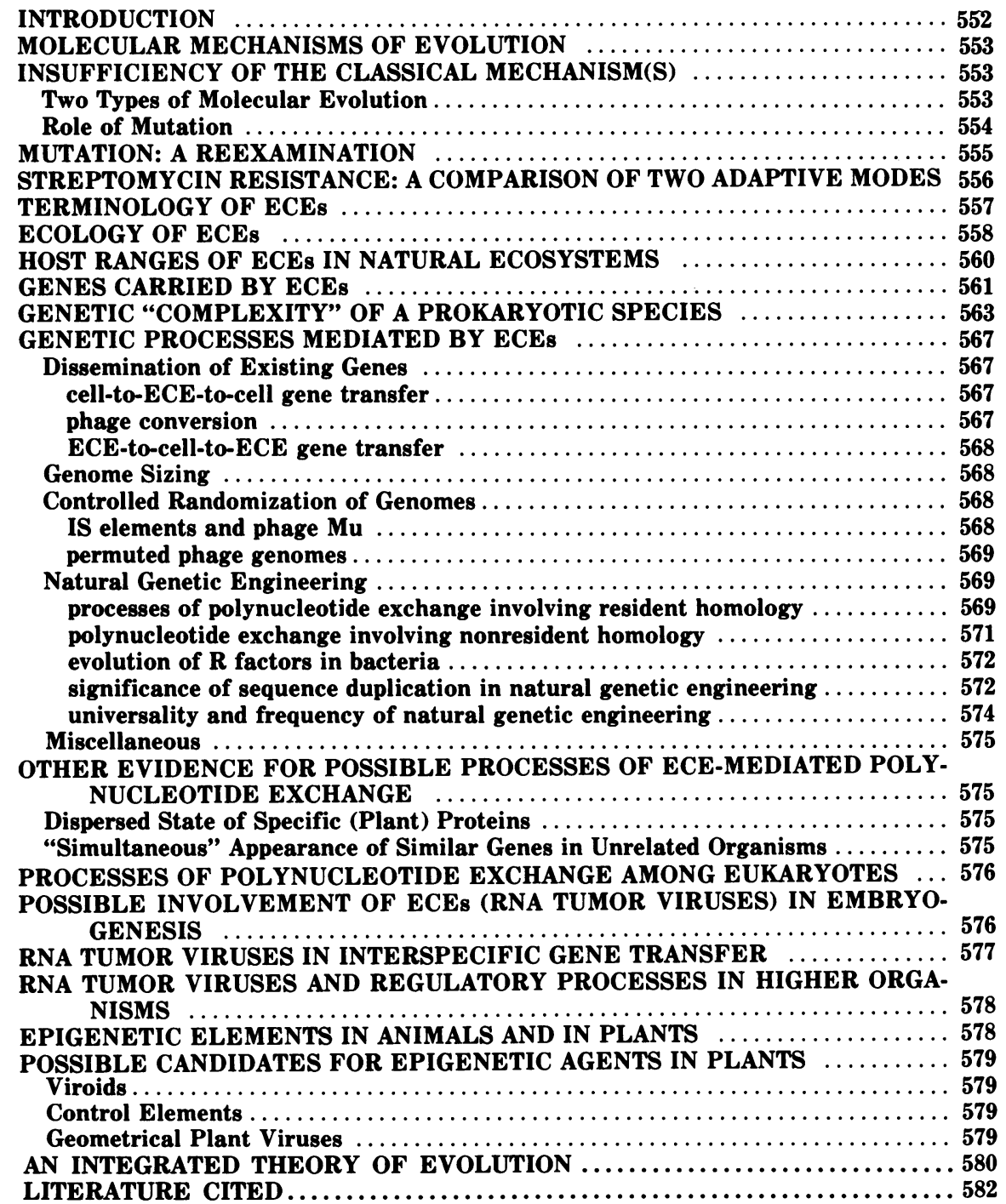

\section{INTRODUCTION}

In 1966, in a perceptive article, Anderson (9) noted "if the long-term activity of transfer factors has influenced (bacterial) evolution, the evolutionary time-scale may have been telescoped into a shorter span than that envisaged purely in terms of the selection of mutants with survival advantages." Four years later a similar adaptive role was proposed for viruses (11). Initial resistance to such ideas (263) has been to some degree eroded by demonstrations that (i) extrachromosomal elements are virtually ubiquitous and (ii) they function in a diverse spec- 
trum of genetic processes. In recent months a number of papers have expanded, supplemented, and reinforced the thesis that extrachromosomal elements can act as agents of accelerated evolution, in both lower and higher forms of life $(209,210,211,249,273)$.

Despite the increasing credence accorded the concept, the ecology of extrachromosomal elements is still poorly documented, theories concerning their phylogeny and interrelationships are speculative, and the terminology applied to such agents remains confused. In many instances, extrachromosomal elements are regarded as bizarre curiosities that are something of an epiphenomenon in general evolutionary biology. The present review attempts to construct a balanced theory of evolution in which proper emphasis is given to possible roles for plasmids and viruses in the processes of growth, adaptation, and speciation.

\section{MOLECULAR MECHANISM(S) OF EVOLUTION}

Since all metabolic functions are catalyzed by enzymes, there is an intuitive tendency to equate molecular evolution with protein evolution. According to this view, all that is exposed to the test of selection is the three-dimensional structure of the folded polypeptide (62). It follows that, for evolution to occur, variation must be introduced into protein structure.

This requirement poses a paradox: if all protein-specifying genes in a cell are essential to life and each gene is represented by only one copy, then a harmful mutation in any gene may kill the organism. Gene duplication is a sine qua non for a continuing evolutionary process: only when duplication liberates a deoxyribonucleic acid (DNA) sequence from the policing action of selection can genetic novelty appear and be tolerated without undue disadvantage to the organism (197). It is now established that many functionally distinct proteins (e.g., trypsin and chymotrypsin, myoglobin and hemoglobin, and the $L$ and $H$ chains of the immunoglobins) were derived by genetic divergence from initially identical duplicate genes.

Genetic divergence may be achieved via point mutations and somewhat less frequently by inversions, deletions, additions, and by gene fusions (271), i.e., the major mutational substratum for evolution in duplicated genes is believed to be random genetic events. This concept-the emergence of novel function by random mutation after gene duplication - will in this paper be termed the "classical" view of molecular evolution. The concept is no longer restricted to proteins after demonstrations that the folded topologies of specific ribonucleic acids (RNAs) (transfer RNA [tRNA], ribosomal RNA [rRNA], low-molecular-weight nuclear RNA) are rigorously conserved by selection. Even genetic molecules may possess "phenotypes" that are subject to selective constraints (177), and in some cases the base sequence of a gene may represent a compromise between the need to maintain a particular folded conformation in the coding RNA on the one hand and in the encoded protein on the other (178). However, pressures of this type may be significant only in tiny entities such as ribophages, where translational controls are built into the structure of the genetic polynucleotide itself $(17,75)$. In the case of eukaryotic cells, there is no evidence to suggest that the phenotypes of monocistronic messenger RNAs (mRNA's) exert an appreciable effect on metabolic fitness.

\section{INSUFFICIENCY OF THE CLASSICAL MECHANISM}

\section{Two Types of Molecular Evolution}

Most research into molecular genetics has been carried out with Escherichia coli and with coliphages. One result has been a tendency to extend uncritically to higher organisms biochemical processes that are well documented in bacteria. The thesis that evolution must proceed through the development of new proteins was challenged by Britten and Davidson (33), who showed how substantial phenotypic novelty could be attained simply by rearranging existing structural genes into different control circuits. The existence and importance of this "second type" of molecular evolution is supported by the studies of Wilson et al. (264). These workers compared the rates of protein evolution with rates of anatomical evolution in selected vertebrate species. The degree of amino acid divergence between albumins from various species was compared with the ability of the relevant species to produce viable hybrid offspring; successful interspecific crosses were regarded as pointing to compatibility between the regulatory circuits of the species. Wilson et al. (264) showed that among the ancient (approximate time of origin, 250 million years ago) and anatomically rather uniform anurans (frogs) very substantial differences in albumin structure did not prevent the formation of hybrids that could metamorphose from tadpole into adult. By contrast, among placental mammals (approximate time of origin, 75 million years ago), which include such anatomically 
diverse organisms as whales, bats, men, and sheep, viable hybrids formed only between species with very similar albumins.

These data suggest that the rate at which mutations accumulate in structural genes does not correlate with the rate of anatomical evolution. The initial studies of Wilson et al. (264) could be criticized on the basis of the fact that only one protein was used to justify the conclusion obtained. However, in a further paper (140), 44 human proteins were compared with 44 chimpanzee proteins of homologous function. The human proteins were, on average, 99\% similar to the chimpanzee proteins. This means that the structural genes for these proteins are as similar as the structural genes of sibling species (145). It is difficult to avoid the inference that organismal evolution is mediated, not by changes in structural genes, but by changes in patterns of gene regulation.

Although the genetic basis of regulatory evolution is still debated, there seems little doubt that repetitive DNA is involved $(33,55,179$, 261). Substantial amounts of repetitive DNA are characteristic of eukaryotic rather than prokaryotic cells (29).

\section{Role of Mutation in Evolution}

The orthodox neo-Darwinian view of evolution predicts that the rate and direction of evolution will be determined by positive selective pressure. However, recent data on protein sequences and enzyme polymorphisms have given rise to the concept that many mutations are selectively neutral and that evolution may proceed at least in part via the random fixation of such neutral mutations $(137,139$; for review, see reference 199). This view has been attacked by defendents of the selectionist position (148, 220). For example, Goodman et al. (85) claim to have demonstrated a Darwinian evolution in the genealogy of the globin group of proteins, whereas Blundell and Wood (26) have described the evolution of insulin mainly in terms of adaptive processes. This issue cannot be resolved at the time of writing, but the neutralists have served to reemphasize the traditional role accorded to chance events in evolution. Ohta (198) points out that random events are likely to be important in molecular evolution in small populations in which a disadvantageous allele may occasionally replace its fitter partner by genetic drift. Monod (180) has cogently argued that mutation is by its very nature a chance event whose intrinsic randomness reflects the statistical basis of the underlying physical events. According to Monod, the stochastic nature of mutation provides an inex- haustible lottery of possibilities such that (moderate) environmental challenges can almost always be matched by an appropriate genetic response.

The stochastic character of mutation is firmly fixed into existing theories of evolution and is supported by an impressive body of experimental evidence. The protective pattern of synonym codons in the genetic code is commonly interpreted as a fail-safe device "designed" to minimize the phenotypic effects of inevitable genetic "errors" $(6,54)$.

The importance of stochastic mutation in adaptation is supported by virtually the entire weight of laboratory studies on monoclonal cultures of microorganisms. Mutants such as $\mathrm{Gal}^{-}, \mathrm{Bio}^{-}$, which are readily obtained by the appropriate selective platings, almost certainly represent the results of rare, randomly introduced genetic changes. Mills et al. (177) have determined the entire primary structure of a self-replicating variant of $\mathrm{Q} \beta$ phage (MDV-1). Kramer et al. (146) then elucidated the base sequence of an MDV-1 mutant obtained by subjecting the replicating variant to concentrations of ethidium bromide that normally inhibit replication. The nucleotide sequence of the mutant was found to differ in three residues from that of the wild type. Since no recombination could have occurred in this in vitro system, the observed changes must have occurred as a result of random errors during RNA synthesis by $Q \beta$ replicase. In assessing the significance of these data, it is important to recall that most "mutant" reference cultures are genetically defective, i.e., auxotrophic mutants represent clones in which genetic function has been lost not gained. It has proven much more difficult to isolate new genes of positive adaptive value under laboratory conditions. Betz et al. (25) have shown that a limited number of mutations in the amidase of Pseudomonas aeruginosa may generate moderate changes in the substrate specificity of the enzyme. However, a carefully planned and executed set of experiments specifically designed to study experimental enzyme evolution failed to develop novel substrate specificities (221): under the conditions employed, the only detectable response to stress was the hyperproduction of preexisting enzymes due to gene duplication.

This result is considered indicative of the moderately low frequency with which useful mutations are introduced into DNA by chance events. I do not deny that evolution may occur via stochastic mutation, but I dispute the significance of such mutation in natural adaptation. In my view (209), the isolation of an organism from its original environment and its 
subsequent propagation by serial passage on defined media under controlled conditions creates a genetic stability that has no parallel in a natural ecosystem. Because of this, stochastic mutation, which I believe to be a minor source of adaptive potential in nature, has been elevated to a status that gives a misleading and inaccurate impression of natural evolution.

To clarify this point, it is necessary to rationalize the terminology used to describe mutations.

\section{MUTATION: A REEXAMINATION}

No system of information transmission can be $100 \%$ efficient (233). It follows that any repeating process of polynucleotide replication will produce some genetic "noise." Such noise may be regarded as a biochemical expression of the second law of the thermodynamics $(79,180)$.

Many biochemists would equate genetic noise with spontaneous point mutations. Point mutations can arise from "copying errors" in polynucleotide synthesis. Accepted mechanisms for such copying errors include tautomerism and ionization of the bases. It has long been obvious that there are substantial discrepancies between observed error rates and those predicted on purely physicochemical grounds: For example, Koch and Miller (144) have used quantitative data (pK values) for the various bases to calculate that spontaneous mutation for all base pair transitions (assuming equal frequency of adenine-thymine [A-T] and guanine-cytosine [G-C] pairs) should amount to 1.3 $\times 10^{-2}$ errors per generation per base pair. An even higher figure can be obtained for the base analogue, bromouracil. At pH 7.2 the spontaneous mutation rate for bromouracil incorporation should be $2 \times 10^{-1}$ per A-T pair.

However, the error rates observed in in vivo reactions are vastly lower than the predicted values. The mutation rate in DNA synthesis is often placed at $10^{-9}(138)$. Trautner et al. have tested the ability of the enzyme polymerase I of $E$. coli to discriminate against "incorrect" bases (256). Their data show that mistakes occur at a rate of less than 1 per $10^{5}$ nucleotides incorporated. The example of adenine-bromouracil polynucleotides is especially instructive. At the $\mathrm{pH}$ used for the enzyme reaction (8.7), bromouracil should be $90 \%$ ionized and thymine should be about $8 \%$ ionized (144), yet the "wrong" base-guanine-is incorporated only once in 2,000 to 25,000 times. It is obvious, therefore, that the polymerases drastically reduce the error rate.

The exact mechanism is still obscure. A primary discrimination must operate at the recog- nition level for individual nucleotides. Koch and Miller (144) suggest that the polymerases possess allosteric sites that select against inappropriate ionic or tautomeric forms of the bases. It is now recognized that polymerases are able to "edit" bases at the replication fork: this is because the $3^{\prime} \rightarrow 5^{\prime}$ exonuclease activity often associated with these enzymes is able to remove mismatched bases erroneously incorporated during polymerization (36). After synthesis a variety of repair enzymes monitor the double helix for local irregularities. The excision-repair mechanism that removes ultraviolet-induced thymine-thymine dimers is well known. Deoxyribonuclease 1, an enzyme from Ustilago maydis, acts preferentially upon the mismatched bases in heteroduplex DNA (5). $N$ glycosidases recognize and remove uracil from DNA-containing deaminated $\mathrm{C}$ residues (155); the lesion may then be repaired by the action of endonuclease $11 / 111$, a polymerase, and a ligase (156).

Hopfield (109) has proposed a further mechanism that would greatly enhance the reliability of information transfer in DNA and protein synthesis. His concept of "kinetic proofreading" in effect invokes a second channel for the rejection of incorrect monomers in any reaction that is strongly but nonspecifically driven by phosphate hydrolysis. Whether this scheme is true or false, it is evident that natural selection has exploited every avenue implicit in protein structure and chemical kinetics to control errors arising during the synthesis of crucial biopolymers.

Shannon's principle (233) states that, although noise can be minimized, it cannot be eliminated entirely. I would like to introduce the term entropic mutation to describe this minimal "scrambling" of the genetic script. A defining feature of entropic mutation is that it is inherently unpredictable, since it has its genesis in uncertainties in the underlying physicochemical events.

Many biologists would apply this term to the bulk of the neutral mutations described by Ohta (199). However, I suggest that entropic mutation, in the strict sense in which it has been defined here, has been a negligible factor in evolution for at least two-thirds of the evolutionary time scale. My reason for this statement resides in the fact that the mutation rate in species that have been carefully studied can be raised or lowered, probably by modulating the ratio of repair/replication. It follows that the rate of mutation is subject to the influence of natural selection. An antimutator strain of phage T4 described by Muzyczka et al. (187) had an error rate less than $10^{-3}$ times that of 
the "wild type." Conversely, mutator loci, which increase the mutation rate, are well documented in $E$. coli (see reference 106). The mut $T$ locus preferentially causes $\mathrm{A}: \mathrm{T} \rightarrow \mathrm{G}: \mathrm{C}$ transversions (52); cells can sustain a load of 7,000 or so such mutations and still remain viable. This means that mutagenic polymerases (and associated enzymes) can affect not only the rate but also the specificity of the mutations they induce. Mutations of this nature cannot be wholly entropic. I propose the term modulated mutation to describe such nonrandom events. This flexible "reliability index" for polymerases enables populations to adjust the amount of genetic variability they contain to suit environmental conditions. Modulated mutations have undoubtedly been significant during evolution, especially in its initial phases. In my view, over $99.9 \%$ of neutral mutations belong in the modulated category.

As a mechanism of adaptation, modulated mutations are not particularly effective. Lowering of the mutation rate (antimutator genes) is advantageous only in an environment so stable that the need for variation is minimal. Mutator loci promote variation but in a largely unselective fashion. Further, in a hypermutating population the "desired" effect of a "good" mutation in a particular locus is likely to be negated by the increased probability that "bad" mutations will inactivate other genes.

I propose that neither entropic nor modulated mutations have been the prime vehicle of adaptive change. The term "mutation" is often used to describe gene inversions, translocations, and duplications (236). Many large-scale genetic rearrangements like gene duplications cannot be "entropic." The fact that, in many cases, the duplicated gene is an exact copy of its progenitor sequence implies that the enzymes involved have functioned correctly and as part of a highly sophisticated mechanism (see the section, Significance of sequence duplication in natural genetic engineering).

I wish to introduce a final and key term programmed variation. The common denominator of programmed variations is the obligatory involvement of recombinational enzyme systems. It is my opinion that higher-order and controlled processes for creating genetic novelty have for many hundreds of millions of years superseded entropic and modulated mutation as the prime source of usable variation in evolution. A consequence of this view is the prediction that a specific enzyme machinery for polynucleotide exchange will be universally distributed throughout the biological world. Evolution based on polynucleotide exchange is relatively efficient, since the participating nucleic acids have already been screened by natural selection $(209,273)$.

The recombination rate, like the mutation rate, may be manipulated by selective pressures. A model for the regulation of recombination in higher organisms, based largely on studies with Neurospora and Schizophyllum, has been proposed by Pandey (205); key features of the model are (i) the frequency of recombination for a given locus is controlled by specific regulatory genes or rec genes (the number of rec loci need not be large if one rec gene can control recombination at many chromosomal sites) and (ii) the dominant rec allele suppresses recombination while the recessive allele promotes it. Thus, outbreeding with its associated high heterozygosity of the rec genes effectively "switches off" recombination; conversely, the homozygosity brought about by inbreeding may introduce large amounts of novel variation. The resulting flexibility might be especially useful in small populations facing changing conditions. Thus, among higher organisms environmental challenges may, to a certain extent, provoke the type of genetic response needed to compensate for them. The model is consistent with many observations: Dewees (61) found dominance in genes that decreased the rate of recombination at a test locus in Tribolium castaneum. Zarachi et al. (272) noted that chiasma frequencies were higher in inbred than outbred wheat populations. However, the converse relationship has been reported by Rees and Thomson (215).

\section{STREPTOMYCIN RESISTANCE: A COMPARISON OF TWO ADAPTIVE MODES}

During recent decades, man has created a stress situation for certain bacteria by introducing into specific ecosystems very high concentrations of antibiotics. All theories of evolution predict that bacteria should adapt to this stress by the acquisition of drug resistance. It is central to the thesis of this article to note that the type of resistance to a drug such as streptomycin developed in the laboratory differs fundamentally from that acquired in nature. Under laboratory conditions, high concentrations of streptomycin select for modulated mutants of $E$. coli in which the $30 S$ ribosomal subunit has been modified (see reference 188). By contrast, the drug-resistant bacteria isolated from environments such as hospitals contain plasmid ( $R$ factor) DNA carrying genes for streptomycinases: such $\mathbf{R}$ factors inactivate streptomycin 
by adenylylation, acetylation, or phosphorylation (20).

In the case of a laboratory population of coliforms, the effectiveness of the adaptive response is hindered by three factors: (i) the genetic diversity of a monoclonal population is rather small; (ii) an absolute limit to the degree of potential genetic flexibility is set by the rate of entropic mutation for any given locus, and (iii) even if a favorable mutant is present in the gene pool, a brake on the speed of its spread is set by the rate at which the organism divides. By contrast, in a natural ecosystem the degree of preexisting, environmentally "tested" variation is vastly greater (section, Genes Carried by ECEs) and further innovations may rapidly be created (section, Natural Genetic Engineering). Further, and here is the key point, extrachromosomal elements (ECEs) have the crucial ability to replicate independently of (and in relaxed strains many times faster than) the genome of the cell. Hence, once a plasmid carrying a favorable gene enters a selectively disadvantaged population, its spread can assume an epidemic character. In this context it is easy to see how selection has created the infective ability of many ECEs, not as a means of bringing about cell death, but as an extraordinarily efficient mechanism of accelerated cell evolution. One must note, however, that it is these very properties - autonomous replication and infectivity - that characterize the "pathological" ECEs. The point has been made elsewhere $(209,211)$ that the emergence of cytopathic viruses may be viewed as an inevitable consequence of the central role played by ECEs in adaptive processes.

Plasmid-mediated adaptation is documented in depth only in the case of drug resistance among the pathogenic microflora. Because of this, the implications of such data for general evolution are not universally accepted. However, Campbell (40) has made the pointed comment "if we ask "how do natural bacterial populations evolve' we probably should not ignore the one case where the process has been observed."

In the remainder of this article I will attempt to show that (i) ECE-mediated adaptive responses may occur in numerous stress situations, and (ii) such mechanisms are not restricted to prokaryotes.

\section{TERMINOLOGY OF ECES}

A diversity of ECEs exist: transfer factors, phages of various kinds, viruses of higher organisms, insertion sequences, etc., and the literature is cluttered with such terms as "plasmid," "exogenote," "episome," and "transposon," to which different authors often impute different meanings (see, for example, reference 72). Confusion is compounded by the fact that one ECE such as $\lambda$ may act as a plasmid, an episome, or a vegetative phage.

To evaluate the proposed adaptive role of ECEs in an unambiguous way, it is necessary to define precisely certain of the terms to be used. The criteria used in the following classification will not find support among all workers in microbiology, and it is hoped that one value of this article will be to draw attention to the pressing need to rationalize the terminology of this field. It should be noted that the definitions adopted below correspond in large measure with the terminology recently proposed by Novick et al. (193).

$E C E$ : This will be retained as a catholic term embracing all extrachromosomal genetic elements, either DNA or RNA; as such, the term includes all viruses, viroids, transfer factors, insertion sequences, and cryptic plasmid DNA. It should be noted that, in terms of this definition, the circular DNA in amphibian oocytes that generates reiterated copies of ribosomal DNA by a rolling circle mechanism (111) is an ECE.

Plasmid: This term is much abused in the current literature. As originally coined by Lederberg (151), the word is a synonym for ECE. However, a number of writers $(92,128)$ have used the word "plasmid" to denote an ECE that is incapable of chromosomal integration. Most reviews give the impression that plasmids include such agents as resistance transfer factors and $F$ but exclude many temperate phages.

Because of the ambiguity surrounding the term I will, where possible, avoid its use in this article and confine myself to the more precise terms defined below. A further reason for this decision lies in the fact that the term is normally applied only to agents infecting bacteria. A prime purpose of this article is to extend the discussion to eukaryotic organisms, and use of the term "plasmid" to describe, for example, a virus like polyoma would not find ready acceptance.

Conjugative plasmid: This term will specifically apply to those agents that may promote their own intercell transfer via conjugation. As such, it is synonymous with the term "transmissable plasmid" as defined by Meynell et al. (176) and includes sex factors, resistance transfer factors, and certain colicinogenic factors. Note that no agents formally analogous to transfer factors are documented among eukaryotes. 
Nonconjugative plasmid: This includes the quiescent "plasmids" listed by Novick (191) and the Col factors, E1-3, K, and X. The phages included in Meynell's classification are excluded from this definition. The grouping of these elements should not be taken to imply any close genetic relationship among them since, as noted by Novick (191), they are rather heterogeneous.

Episome: This useful term is often criticized by those who use it most frequently (see, for example, 39). In this article "episome" will be used in the broadest taxonomic sense to describe any transmissible ECE that can integrate into and/or excise from cellular DNA. Thus it covers conjugative plasmids such as $\mathrm{F}$, phages such as $\lambda$, and also eukaryote viruses such as the papovavirus and oncornavirus groups.

Virus: This term basically refers to the huge group of entities that promote the transfer of their genetic material from cell to cell by means of discrete particles. The genetic material of viruses is protected by surrounding protein, lipoprotein bilayer membranes, or both.

Control element: The molecular nature of the "control element" described by McClintock (163) in maize is unknown, but its properties of self-amplification and translocation suggest that it is probably an ECE of some kind.

Cryptic circular DNA (cc DNA): (Conjugative and nonconjugative plasmids, viruses, and control elements) do not encompass all the ECEs documented in various systems. The most common type of element not covered by any of the above may be the circular DNAs detected in a variety of cells (see, for example, Cozzarelli et al. [53]). The ability of such cyclic DNAs to selfamplify and infect other cells is in many instances not documented.

The terms "viroid" and "insertion sequence" (IS) retain the specialized meanings imputed to them by the authors who coined them.

The reader should note that the above categories exist purely for descriptive convenience; they imply nothing about phylogenetic relationships between the various entities.

\section{ECOLOGY OF ECES}

ECEs are best documented among prokaryotes. Gyles and co-workers (89) have estimated that extrachromosomal replicons may occur in $50 \%$ of all naturally occurring strains of Enterobacteriaceae. The frequency of lysogenic strains in the genus Pseudomonas has been placed as high as $100 \%$ (see reference 108). The full spectrum of such ECEs has probably not been uncovered, because few systematic ecological studies have been performed and be- cause gene rearrangements may be creating novel ECE DNAs more or less continuously. However, the number of plasmids in coliforms is likely to be very large: Novick (192) lists 269 known "plasmids" for $E$. coli. Turning to viruses, 30 different prophages are documented among coliforms (68). When all types of known coliphage are listed the total, at the time of writing, stands at 87 . The functional and genetic diversity of coliphages is striking; the list (Table 1) includes lytic T-even phages whose DNA is circularly permuted and terminally redundant (252), T-odd phages such as T5 whose DNA is transferred into recipient cells by a twostep process (149), lambdoid phages whose DNA is unique but terminally cohesive, filamentous phages that are released from growing cells without markedly harming the infected culture (170), mutator phages such as $\mathrm{Mu}(250)$, RNA phages that adsorb specifically to the pili of cells harboring conjugative plasmids, and icosahedral phages such as $\phi \mathrm{X} 174$ that contain single-stranded circular DNA.

The ecology of these phages is poorly documented. However, since samples of sewage from various parts of the world have yielded very similar phages, it seems likely that all natural coliform populations harbor the bulk of these ECEs.

cc DNAs are well documented in coliforms. Christiansen et al. (47) examined 87 different strains of enterobacteria and pseudomonads. Thirty-four strains contained closed circular DNA varying in size from 0.5 to $40 \mu \mathrm{m}$; many organisms contained multiple cc DNAs.

I am most familiar with members of the genus Bacillus. Conjugative plasmids have not been identified for gram-positive bacilli. However, plasmid-like circular DNA has been reported in several species and is probably common: for example, about $2 \%$ of the DNA of certain strains of $B$. pumilus can be isolated as covalently closed circular molecules (160); 2 of 18 strains of $B$. subtilis examined by Lovett and Bramucci (159) contained circular DNA of homogeneous size and buoyant density. About $30 \%$ of the DNA of $B$. megaterium 216 consists of minicircles that exhibit extensive base homology with host cellular DNA (104). However, the "plasmid" status of this material is doubtful. Much of the difficulty in detecting plasmids in Bacillus lies in the apparent absence of a convenient screening system such as resistance to antibiotics. The only known instance of a correlation between the presence of a plasmid and a phenotypic property of the host is the altered sporogenic ability of $B$. pumilus NRS 576 on loss of the plasmid pPL576 (158).

The ECEs most abundantly represented in 
TABle 1. Phages of E. coli $^{a}$

\begin{tabular}{|c|c|c|c|c|c|}
\hline \multicolumn{5}{|c|}{ DNA phages } & \multirow{3}{*}{$\begin{array}{l}\text { RNA phages (sin- } \\
\text { gle stranded; iso- } \\
\text { metric; plasmid de- } \\
\text { pendent) }\end{array}$} \\
\hline \multicolumn{2}{|r|}{ Duplex (tailed) } & \multicolumn{2}{|c|}{ Single stranded } & \multirow{2}{*}{ Unclassifiedc } & \\
\hline Type & Members & Isometric $^{b}$ & Filamentous $^{b}$ & & \\
\hline $\begin{array}{l}\text { A1 } \\
\text { A2 }\end{array}$ & $\begin{array}{l}\text { E1, Mu1, PK, } 186 \\
0111, \mathrm{~T} 2, \mathrm{~T} 4, \mathrm{~T} 6, \\
\alpha 1,3\end{array}$ & $\begin{array}{cc}\mathrm{X} 174, & \mathrm{~S} 13, \\
\phi \mathrm{R}, & \mathrm{ST} 1, \\
\alpha 3 & \end{array}$ & $\begin{array}{l}\text { fd, fl, M13, ZJ/2, } \\
\text { Ec9, AE2, } \\
\text { HR, } \delta A\end{array}$ & $\begin{array}{c}\text { P1, } \phi R, \text { C16, D108, } \\
\text { E1, } \Omega 8, \text { Plkc, P2, } \\
\text { 13vir, 15, Dd-Vi, } \\
\text { N15, } \phi N, \text { DD7 }\end{array}$ & $\begin{array}{l}\text { M12, fr, } \beta, \text { FH5, } \\
\text { FcanI, } \mu 2, \mathrm{ZJ} / \\
1, \mathrm{Z}, \mathrm{Y}\end{array}$ \\
\hline B1 & $\begin{array}{l}\text { q, T1, T3C, T5, } \\
\beta 4, \lambda, \phi 80, \chi, 2, \\
4,6,3000, \mathrm{C} 1, \\
\text { DDUP }\end{array}$ & & & & $\begin{array}{c}\text { f2, R17, MS2, ZR } \\
\text { GA, SD SP F1 } \\
\text { Q } \beta \text {, VK, ST }\end{array}$ \\
\hline $\begin{array}{l}\text { B2 } \\
\text { C1 }\end{array}$ & $\begin{array}{l}\mathrm{ZG} / 3 \mathrm{~A}, 5 \\
\mathrm{~N} 4, \mathrm{~S}_{\mathrm{d}}, \mathrm{T} 3, \mathrm{~T} 7, \\
\phi 04-\mathrm{CF}, 1,8\end{array}$ & & & & \\
\hline C3 & F46/3039, NN & & & & \\
\hline
\end{tabular}

a The morphological grouping of the tailed bacteriophages is based on the description given by Ackermann (1). Phages have been classified according to this grouping (2). Data relating to the isometric phages are given in reference 267.

These are all very similar.

c These DNA phages are as yet inadequately classified. Note that some of them may represent phages already isolated and characterized.

d All these ribophages are similar in physical properties.

this group may be phages. Over 150 Bacilius phages have been reported $(1,2,211)$. We have little doubt as to the ubiquity of phages for this genus. In our experience, any indicator Bacillus strain will show up one or more plaques when supernatant from enriched soil is plated out under the appropriate conditions. The greatest number of phages found to date on any one culture appears to be the 15 distinct viruses able to infect $B$. pumilus W43 (214). High phage titers are usually attained in enriched soil, often of the order of $10^{10}$ plaque-forming units/g for a given phage (212). Since many hundreds of distinct phages probably exist in most surface soil samples, the total virus population in $1 \mathrm{~g}$ of soil under optimal conditions may exceed $10^{13}$ particles. Under these conditions, there is no doubt that viruses are the most numerous genetic objects in this ecosystem (209).

Szybalski and Szybalski (249), in pointing out that as much as $30 \%$ of the DNA of $E$. coli may consist of prophage, note that the distinction between "phage" DNA and "cellular" DNA may not be particularly meaningful. Similarly, a fraction of the DNA of Bacillus species almost certainly consists of ECE genes. Cultures induced by treatment with $\mathrm{H}_{2} \mathrm{O}_{2}$, ultraviolet or mitomycin $\mathrm{C}$ have been shown to contain a defective phagelike particle $(117,214,230 ; \mathrm{F}$. A. Eislering, Ph.D. thesis, Univ. of California, Los Angeles 1964; W. Kelly and D. Reanney, unpublished observations). A substantial num- ber of temperate phages are known for Bacillus species $(51,211)$. Our data (Kelly and Reanney, unpublished observations) and those of Ackerman and Smirnoff (3) suggest that many bacilli in this genus are polylysogens. Polylysogeny occurs frequently in other genera: for example, one strain of Pseudomonas has been reported to harbor 8 to 10 different prophages (see reference 108). However, the phenomenon of pseudolysogeny is also common in Bacillus $(31,224)$, and many phage genomes may never enter into a stable association with chromosomal DNA. The abundant presence of prophages in this genus suggests that the cell-to-cell passage of plasmid DNA may be mediated by transducing viruses. In other gram-positive eubacteria such as staphylococci, which also lack conjugative plasmids, the interstrain transfer of plasmidborne drug resistance is achieved by transduction (194; see section, cell-to-ECE-to-cell gene transfer).

The (apparent) absence of conjugative plasmids from the genus Bacillus possibly reflects the fundamental ecological differences that exist between the habitats of coliforms and sporeforming bacilli. In the gut of vertebrates where large coliform populations exist in a substraterich, fluid medium the chances of successful cell-to-cell mating are high. The colloidal and particulate character of soil, and the variable nature of such factors as $\mathrm{pH}$, temperature, and nutrient supply, mean that bacteria in soil will, under most conditions, be less likely to be in a 
state of adequate physical proximity and metabolic fitness to permit an efficient process of gene transfer by connecting pili. Hence, in soil, selection may have acted to promote cell-to-cell transfers by means of the smaller, more easily diffusible and dispersible phage particles. The ability of phages to survive in spores (31) is probably a further adaptive reflection of the differing problems faced by Bacillus species compared with coliforms.

Passing from prokaryotes to eukaryotes, conjugative plasmids have not been documented among eukaryotes, and theoretical considerations suggest that such elements could serve fewer useful functions in metazoan organisms than in unicellular organisms. cc DNA is known; for example, the small circular nonmitochondrial DNA molecule observed in yeast by Guerineau et al. (88) has been suggested to be the agent responsible for oligomycin resistance in this organism. However, apart from control elements (163), about which little is known, the most common ECEs in eukaryotes appear to be viruses. Viruses are known for most of the major phyla. For any given vertebrate, the number of associated viruses may run into thousands. Little systematic ecological work has been done on eukaryote viruses, with the exception of those few viruses pathogenic to man.

Just as the distinction between cellular and viral DNA is blurred in bacteria, so among vertebrates it has become increasingly difficult to treat the type $\mathrm{C}$ oncornaviruses as agents "foreign" to the host chromosomes $(119,251$, 209,211 ). Endogenous oncornaviruses containing the enzyme reverse transcriptase have been reported in each vertebrate species carefully examined for them. In particular, class I viral genes (82) appear to be universally present in vertebrate chromosomes. At this point the arguments for the ubiquity of ECEs become circular. If, as Szybalski and Szybalski (249) and others believe, the chromosomes of all organisms contain viral "modules" that may occasionally acquire replicative autonomy, then it follows that ECEs will be universally distributed throughout the biosphere (see section, Natural Genetic Engineering.)

\section{HOST RANGES OF ECES IN NATURAL ECOSYSTEMS}

The question of host ranges for ECEs such as phages appears to have been investigated on a piecemeal basis. Among Bacillus species, it is easy, from published reports, to gain the impression that phages are rather restricted in their host range(s). Phage $\mathrm{W}$, studied by McCloy (164), when tested for lytic activity against
244 Bacillus cultures, would lyse only strains of $B$. anthracis and B. cereus. Phage TP-84 lysed only 3 of 24 strains of $B$. stearothermophilus (227). Because of their presumed species specificity, phages are often used in the taxonomic identification of unknown organisms (238).

In assessing the significance of such data we were impressed by the fact that in every case known to us the phages and the indicator bacteria had not been isolated from the same ecosystem. A priori, it seems unrealistic to expect that a monoclonal culture of a given bacterium isolated from a particular soil in one part of the world will display towards a particular phage the same susceptibility as a culture isolated from an ecologically distinct and geographically remote soil sample. We therefore determined the host ranges of a variety of Bacillus phages isolated from roughly the same soil ecosystem as a group of bacterial colonies picked at random. Table 2 shows a typical t of results. Of 38 bacteria, only one was resistant to all 29 phages. Only one phage-K19-could not lyse any of the bacteria. For the rest, Table 2 reveals a broad spread of phage susceptibility such that $30 \%$ of the phages can infect between 60 to $83 \%$ of the bacteria. We conclude that the use of international reference cultures as indicator bacteria for newly isolated phages may give a misleading and restricted picture of the natural host ranges of such viruses (214).

Table 3 shows the same 29 soil phages tested against 25 known cultures of Bacillus. It is clear that most of the phages have host ranges that cross species lines. There is no necessary correlation with bacterial taxonomy. The authentic $B$. pumilus ATCC 7061 is not lysed by any of 22 phages originally isolated on $B$. pumilus W43 (214). Phage K13 lyses 15 of 26 strains distributed among six species, some of which are considered taxonomically distant by Smith et al. (238).

Turning to the coliform group, we find a rather similar picture. Although many coliphages appear to have limited host ranges, a substantial number do not. P1 infects not only Escherichia spp. but also Salmonella, Shigella, and Klebsiella, whereas Kaiser and Dworkin (132) have recently shown that $\mathrm{Pl}$ can transfer genes from $E$. coli to a myxobacterium. Wide host ranges seem to be more characteristic of the generalized transducing phages than those mediating specialized transduction. However, it is among the conjugative plasmids that one finds the highest degree of communicability between species. An R factor such as RP4 can infect virtually all members of the enteric microflora and several free-living species (57, 58, 126, 192, 202, 248; see Table 4). 


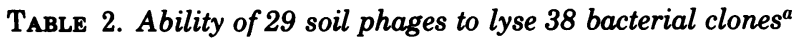

\begin{tabular}{|c|c|c|c|c|c|c|c|c|c|c|c|c|c|c|c|c|c|c|c|c|c|c|c|c|c|c|c|c|c|}
\hline \multirow{2}{*}{$\begin{array}{l}\text { Bacterial } \\
\text { clone no. }\end{array}$} & \multicolumn{29}{|c|}{ Lysis with phage: } \\
\hline & K1 & $\mathbf{K} 2$ & K3 & K4 & K6 & K7 & K8 & K9 & $\begin{array}{l}\mathrm{K} \\
11 \\
\end{array}$ & $\begin{array}{l}\mathrm{K} \\
12 \\
\end{array}$ & $\begin{array}{r}\mathbf{K} \\
\mathbf{1 3}\end{array}$ & $\begin{array}{r}K \\
14 \\
\end{array}$ & $\begin{array}{c}\mathbf{K} \\
15\end{array}$ & $\begin{array}{r}K \\
17 \\
\end{array}$ & $\begin{array}{l}K \\
18 \\
\end{array}$ & $\begin{array}{l}K \\
19 \\
\end{array}$ & $\begin{array}{l}\mathbf{K} \\
20 \\
\end{array}$ & $\begin{array}{l}\mathrm{K} \\
21 \\
\end{array}$ & \begin{tabular}{|c|}
$\mathbf{K}$ \\
$\mathbf{2 2}$ \\
\end{tabular} & $\begin{array}{c}\mathrm{K} \\
18_{1} \\
\end{array}$ & D-6 & L1 & $\mathbf{L 2}$ & L3 & C1 & C2 2 & C3 C & $\mathrm{C} 4 \mathrm{C}$ & C5 \\
\hline 1 & -6 & + & + & - & + & + & - & - & - & $\mathbf{f}$ & + & - & - & id9 & $\mathbf{f}$ & - & + & - & $+t$ & $\mathbf{f}$ & $+\mathrm{t}$ & f & - & f & - & f & - & f & \\
\hline 2 & - & - & - & - & - & - & - & - & - & - & - & - & - & -1 & - & - & - & - & - & - & - & - & - & - & $+\mathrm{t}$ & - & - & - & \\
\hline 3 & - & f & f & - & - & - & - & - & - & - & $+\mathrm{c}$ & - & f & - & $\mathbf{f}$ & - & f & $\mathbf{f}$ & f & - & $+c$ & $+\mathrm{c}$ & - & $+\mathrm{c}$ & -1 & $+\mathrm{c}$ & & $+c$ & \\
\hline 4 & - & - & - & - & - & - & - & - & - & - & - & - & - & - & - & - & - & - & - & - & - & - & - & - & - & -1 & - & - & - \\
\hline 5 & - & - & - & - & - & - & - & - & - & - & - & - & - & - & + & - & - & - & - & - & - & - & - & - & - & - & - & - & - \\
\hline 6 & $+\mathrm{t}$ & $+\mathrm{c}$ & $+\mathrm{t}$ & - & - & - & $+\mathrm{t}$ & - & f & $+\mathrm{t}$ & $+\mathrm{t}$ & - & f & + & $+t$ & - & $+c$ & $+\mathrm{t}$ & $+c$ & $+\mathrm{t}$ & $+t$ & - & - & $+\mathrm{t}$ & - & $+\mathrm{t}$ & - & $+t$ & \\
\hline 7 & - & - & - & - & - & - & - & - & - & - & - & - & - & - & $+t$ & - & - & - & - & - & $+\mathrm{t}$ & - & - & $\mathbf{f}$ & $\mathbf{f}$ & $\mathbf{f}$ & - & f & f \\
\hline 8 & - & f & f & - & - & - & - & - & - & - & + & - & f & - & $+t$ & - & $+t$ & f & f & f & + & + & + & + & + & + & + & + & + \\
\hline 9 & - & f & $\mathbf{f}$ & - & - & - & - & - & - & - & $+\mathrm{t}$ & - & - & - & $+\mathrm{t}$ & - & f & - & f & $+\mathrm{t}$ & - & $+c$ & - & $+c$ & - & f & - & $+t$ & - \\
\hline 10 & f & $+c$ & $+c$ & - & - & $-\mathbf{f}$ & $+t$ & - & - & f & $+c$ & $+t$ & $+t$ & & $+\mathrm{t}$ & - & + & $+t$ & $+t$ & $+\mathrm{t}$ & f & $+\mathrm{t}$ & - & $+\mathrm{t}$ & - & $+\mathbf{t}$ & $-1+$ & $+\mathrm{t}$ & - \\
\hline 11 & - & f & -1 & - & - & - & - & - & - & - & + & - & - & - & - & - & - & - & - & - & + & + & - & + & - & $+i$ & id3 + & + & - \\
\hline 12 & - & f & f & - & - & - & - & - & - & - & f & - & - & - & $+t$ & - & f & - & - & - & - & - & - & f & - & -1 & $-1-$ & - & \\
\hline 13 & - & - & $\mathbf{f}$ & - & - & - & - & - & - & - & f & - & - & - & $+c$ & - & f & - & - & $+t$ & - & - & - & f & - & - & - & - & \\
\hline 14 & - & - & - & - & - & - & - & - & - & - & - & - & - & - & + & - & - & - & - & + & - & - & - & - & - & - & - & - & 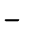 \\
\hline 15 & - & f & f & - & - & - & - & - & - & -1 & $+\mathrm{t}$ & - & - & - & $+t$ & - & $+\mathrm{t}$ & - & f & - & $+\mathrm{t}$ & $+\mathrm{t}$ & $+c$ & $+\mathrm{t}$ & $+c$ & $+\mathrm{t}$ & $+c$ & $+\mathrm{t}$ & $+c$ \\
\hline 16 & - & $f$ & f & - & - & - & - & - & - & - & + & - & - & - & $+t$ & - & $\mathbf{f}$ & f & f & $+\mathbf{c}$ & - & + & + & + & + & $+\mathrm{t}$ & + & + & + \\
\hline 17 & - & $+?$ & $+?$ & - & - & - & - & - & - & - & $+?$ & - & - & - & $\mathbf{f}$ & - & - & - & - & $+c$ & $+c$ & $+\mathrm{c}$ & $+c$ & + & $+c$ & + & + & $+c$ & - \\
\hline 18 & - & - & -1 & - & - & - & - & - & - & - & - & - & - & - & - & - & - & - & - & - & - & - & - & - & - & - & - & - & - \\
\hline 19 & - & f & f & - & - & - & - & - & - & - & $+t$ & - & - & - & $+\mathrm{t}$ & - & f & - & - & $+\mathrm{t}$ & $+c$ & $+\mathrm{t}$ & - & $+t$ & - & $+\mathrm{t}$ & - & $+\mathrm{t}$ & - \\
\hline 20 & - & - & - & - & - & - & - & - & - & - & - & - & - & - & + & - & - & - & - & - & - & - & - & - & - & -1 & - & - & - \\
\hline 21 & - & f & f & - & - & - & - & - & - & - & $+c$ & - & - & - & f & - & f & - & - & - & $+c$ & $+\mathrm{t}$ & $+\mathrm{t}$ & $+t$ & $+t$ & $+\mathbf{t}$ & $+\mathrm{t}+$ & $+\mathbf{t}$ & $+\mathrm{t}$ \\
\hline 22 & - & - & - & - & - & - & - & - & - & - & - & - & - & - & f & - & - & - & - & - & - & - & - & - & - & -1 & - & - & \\
\hline 23 & - & f & f & - & - & - & - & - & - & - & f & - & - & - & f & - & $\mathbf{f}$ & - & - & - & - & $+\mathrm{t}$ & - & $+\mathrm{t}$ & - & + & - & $+t$ & - \\
\hline 24 & - & f & f & - & - & - & - & - & - & - & + & - & f & - & $+\mathrm{t}$ & - & $+t$ & f & $+t \mid$ & $\mathbf{f}$ & id11 & + & + & + & + & + & + & + & + \\
\hline 25 & - & $+t$ & $+\mathrm{t}$ & - & - & f & f & f & f & f & $+\mathrm{t}$ & - & f & - & $+t$ & - & $+\mathrm{t}$ & f & $\mathbf{f}$ & $\mathbf{f}$ & $\mathbf{f}$ & $+\mathrm{t}$ & - & $+\mathrm{t}$ & - & + & - & $+\mathrm{t}$ & - \\
\hline 26 & - & - & - & - & - & - & - & - & - & - & - & f & - & - & + & - & - & - & - & + & - & - & - & -1 & - & - & - & - & - \\
\hline 27 & - & $\mathbf{f}$ & f & - & - & - & - & - & - & - & f & - & - & - & $+\mathrm{t}$ & - & $\mathbf{f}$ & - & - & - & - & $\mathbf{f}$ & - & f & - & f & - & $\mathbf{f}$ & - \\
\hline 28 & - & - & - & - & - & - & - & - & - & - & + & - & - & - & - & - & - & - & - & + & - & f & - & f & - & - & - & - & - \\
\hline 29 & - & f & f & - & - & - & - & - & - & - & f & - & - & - & f & - & f & - & - & - & - & f & f & f & f & $+\mathrm{t}$ & f & f & f \\
\hline 30 & - & - & - & - & - & - & - & - & - & - & - & - & - & - & + & - & - & - & - & - & - & - & - & - & - & - & - & - & - \\
\hline 31 & - & - & - & - & - & - & - & - & - & - & - & - & - & - & + & - & - & - & - & + & - & $\mathbf{f}$ & - & $\mathbf{f}$ & - & $\mathbf{f}$ & - & -1 & - \\
\hline 32 & id1 & f & f & - & - & - & - & - & - & - & $+\mathrm{t}$ & - & - & - & f & - & f & - & - & - & - & $+\mathrm{t}$ & $\mathbf{f}$ & $+\mathrm{t}$ & $+\mathrm{t}$ & $+\mathrm{t}$ & + & $+\mathrm{t}$ & $\pm t$ \\
\hline 33 & $\mathbf{f}$ & f & $\mathbf{f}$ & - & - & - & - & - & - & - & + & id10 & - & - & $+\mathrm{t}$ & - & $\mathbf{f}$ & - & $\mathbf{f}$ & - & $+t$ & $+\mathrm{t}$ & - & + & - & $+\mathrm{t}$ & - & $+\mathrm{t}$ & - \\
\hline 34 & - & + & + & f & - & f & - & - & - & f & $+\mathrm{t}$ & - & - & - & + & - & + & - & - & - & + & $+\mathrm{t}$ & + & $+\mathrm{t}$ & + & $+t$ & $+t$ & + & $+\mathrm{t}$ \\
\hline 35 & f & f & f & - & - & - & - & - & - & - & - & - & - & - & - & - & f & - & f & - & f & $+\mathrm{t}$ & - & $+\mathrm{t}$ & -1 & $\mathbf{f}$ & - & f & - \\
\hline 36 & - & - & - & - & - & - & - & - & - & - & - & - & - & - & - & - & - & - & - & - & - & $\mathbf{f}$ & - & + & - & - & - & - & - \\
\hline 37 & - & f & f & - & - & - & - & - & - & - & f & - & - & - & f & - & $\mathbf{f}$ & - & f & f & f & $+\mathrm{t}$ & - & $+\mathrm{t}$ & - & f & - & f & - \\
\hline 38 & - & - & + & - & - & - & & & - & - & + & & - & - & + & - & - & - & - & + & - & & - & $\mathbf{f}$ & - & f & - & - & - \\
\hline
\end{tabular}

a The 29 phages were isolated from local soil to lyse 38 bacterial clones isolated from the same locality. Phages prefixed with " $\mathrm{K}$ " were isolated on $B$. pumilus W43; phages prefixed with L were isolated on B. licheniformis; and those prefixed with C were isolated on $B$. circulans. Phage D-6 was isolated on B. stearothermophilus. The 38 soil bacteria have not been identified (Reanney and Dodds, unpublished data).

- + , Clear lysis; +c, clear lysis with some colonies; +t, turbid lysis; $f$, lysis faint but detectable; id, individual plaques.

Among higher organisms, we find a substantial disparity between the host ranges of viruses of plants and of animals. Plant viruses may have wide host ranges. Alfalfa mosaic virus can infect 222 species of plants (56); tobacco ringspot infects 246 species distributed throughout 54 families (237). Some reasons for, and consequences of, these wide host ranges have been discussed by Reanney $(209,211)$. Among higher animals, host ranges for most viruses seem severely restricted. However, vesicular stomatitis virus can infect a diversity of mammals, whereas polyoma can infect rats, rabbits, mice, and hamsters. Certain rhabdovirions can multiply in such taxonomically diverse hosts as insects, vertebrates, and angiosperms. It is clear, therefore, that viruses, as a group, are to varying degrees independent of conventional phylogenetic relationships in that they possess the ability to transfer genes across tolerably wide taxonomic gaps.

\section{GENES CARRIED BY ECEs}

The medical threat posed by multiple drug resistance has "publicized" the ECEs (R factors) responsible (10). Table 5 shows that such elements can carry genes for resistance to at least seven different antibiotics, seven heavy metal poisons, and to ultraviolet, colicins, and phages. Since all of these agents are bacteriocidal, the selective advantage accruing to an organism carrying such genes, either singly or more especially in combination, is obvious. However, if the general thesis of the article is 


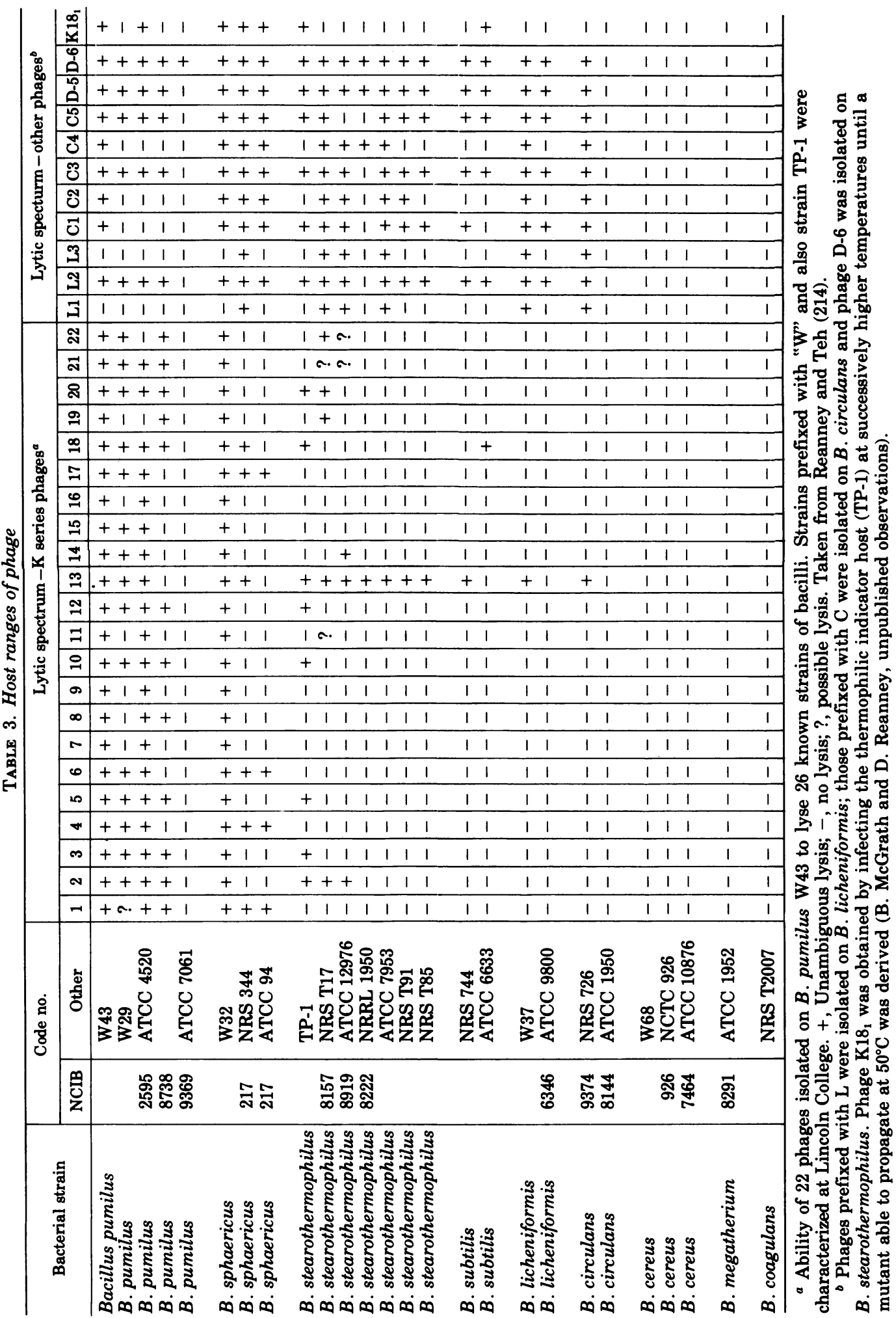


TABLE 4. Genera able to accept naturally occurring plasmids isolated from the Enterobacteriaceae or Pseudomonadaceae

\begin{tabular}{lc}
\hline \multicolumn{1}{c}{ Genus } & Source \\
\hline Acinetobacter & 218 \\
Aeromonas & 192 \\
Agrobacterium & 192 \\
Azotobacter & 218 \\
Chromobacterium & 192 \\
Citrobacter & 192 \\
Enterobacter & 192 \\
Erwinia & 192 \\
Escherichia & 192 \\
Klebsiella & 192 \\
Proteus & 192 \\
Providencia & 192 \\
Pseudomonas & 192 \\
Rhizobium & 192 \\
Rhodopseudomonas & 218 \\
Rhodospirillum & 218 \\
Salmonella & 192 \\
Shigella & 192 \\
Serratia & 192 \\
Vibrio & 192 \\
Yersinia & 192 \\
\hline
\end{tabular}

correct, then plasmids should be able to carry a biochemically diverse spectrum of genes. Accordingly, we find among pseudomonads a group of conjugative plasmids carrying genes for early steps in peripheral metabolic pathways: such genes code for enzymes able to degrade camphor (217), octane (42), salicylate (41), and napthalene (70). Not all genes carried by conjugative plasmids code for "dispensible" functions. $\mathrm{F}$ has recently been shown to promote the turnover of "stable" (67) RNA in $E$. coli (196). Of the two loci involved (termed srnA and srnB) the srnB gene(s) appears to be located on the F plasmid (196). The R-Utrecht plasmid codes for an enzyme similar to $E$. coli DNA polymerase I (165). Although this enzyme is implicated in the ultraviolet resistance conferred by the plasmid, an essential role for polymerase I in chromosomal replication seems established (201).

The genetic flexibility of conjugative plasmids has been abundantly confirmed in the laboratory. Low (161) has described $171 \mathrm{~F}^{\prime}$ factors for $E$. coli $\mathrm{K}-12$. It seems very probable that any genetic marker in the coliform map can become incorporated into such a factor. The Srn phenotype conferred by F (196) may imply that the classical F (Hayes) factor merely represents a specific, stable $F^{\prime}$ element that has attained an unrepresentative prominence because of its widespread use as a laboratory tool and its status as the "archetypal" conjugative plasmid.

The integration of any plasmid into cellular
DNA, irrespective of any genes carried by the DNA, can markedly affect the genetic and metabolic state of the organism. Many ECEs encode their own specific endonucleases (often restriction endonucleases, as in the case of $R \cdot E c o \cdot R I$ [100] for the R1 conjugative plasmid), site-specific transferases, and other autoreplicative functions. The most significant consequence of the new enzyme activities sometimes introduced by ECEs may be the enhanced potential for natural "genetic engineering" under various selective pressures (see section, Natural Genetic Engineering).

Clearly, these consequences of infection by conjugative plasmids apply with equal validity to the infection of a cell by a temperate phage. Lambdoid phages such as $\lambda$ and $\phi 80$ also encode sequence-specific endonucleases, in addition to sequence-specific repressors (168). Also, some phages, like plasmids, appear to carry some "somatic" (191) genes, e.g., tox in phage $\beta$ as quasipermanent parts of their genomes (Table 7). The phage-specific functions that result in the induction and repression of L-arabinose isomerase in P22-infected Salmonella typhimurium (43) are not conversion genes, but they do indicate the diversity of metabolic side-effects that may accompany infection.

The situation in eukaryotes is less well documented. The papovaviruses, polyoma and simian virus 40 (SV40), can carry genes of cellular origin in the so-called pseudovirions (12). It appears as though the degradation of mouse embryo DNA to produce the encapsidated fragments is relatively specific (266). Similarly, Ikawa et al. (122) have shown that type C RNA tumor viruses grown in erythroblasts can incorporate globin mRNA's; if this is a general feature of the oncornaviruses then perhaps an RNA equivalent of any gene may become incorporated into such particles.

\section{GENETIC “COMPLEXITY” OF ANY PROKARYOTIC SPECIES}

Table 3 gave the host range characteristics of 15 phages isolated on $B$. pumilus W43 which have been studied in our laboratory in some detail. Figure 1 shows the cell-to-cell connections made possible by these phages (214). To prove that these connections result in a flow of genes along the pathways mapped would require a rigorous demonstration that the phages can transduce cellular DNA. That this is likely to be the case for at least some of the phages is strongly suggested by existing data. Romig (224) has noted that pseudolysogenic phages for the genus Bacillus are often capable of generalized transduction. Table 6 shows that transducing phages are documented for $B$. amylolique- 
TABLE 5. Some of the diverse genes carried by ECEs

\begin{tabular}{|c|c|c|c|}
\hline ECE & Phenotype & Genetic marker $^{a}$ & Source \\
\hline \multicolumn{4}{|l|}{ Resistance genes } \\
\hline $\mathbf{P}+\mathbf{R}$ & Penicillin & penI and penB, penZ & \\
\hline $\mathbf{R}$ & Streptomycin & str & \\
\hline $\mathbf{R}$ & Neomycin & neo & \\
\hline $\mathbf{R}$ & Chloramphenicol & $\operatorname{chl}$ & \\
\hline $\mathbf{P}$ & Erythromycin & ero & \\
\hline $\mathbf{R}$ & Kanamycin & kan & \\
\hline $\mathbf{R}$ & Tetracycline & tet & \\
\hline $\mathbf{P}$ & Arsenate & asa & \\
\hline $\mathbf{P}$ & Arsenite & $a s i$ & \\
\hline $\mathbf{P}$ & Bismuth & bis & \\
\hline $\mathbf{P}$ & Lead & lea & 191 \\
\hline $\mathbf{P}, \mathbf{R}$ & Mercury & mer & \\
\hline $\mathbf{P}$ & Cadmium & $\operatorname{cad}$ & \\
\hline $\mathbf{R}$ & Nickel & nic & \\
\hline Col, R(i) & Colicin & col & \\
\hline F & Phages & $s p p$ & 191 \\
\hline Col1 ColB & Ultraviolet light & uvr & \\
\hline$R(i) R(f)$ & & & \\
\hline \multicolumn{4}{|c|}{ Early steps in peripheral metabolic pathways (pseudomonads) } \\
\hline $\mathbf{R}$ & Enzymes degrading camphor & cam & 217 \\
\hline $\mathbf{R}$ & Octane & oct & 42 \\
\hline $\mathbf{R}$ & Salicylate & sal & 41 \\
\hline $\mathbf{R}$ & Napthalene & nah & 70 \\
\hline $\mathbf{R}$ (fused) & Camphor and octane & cam-oct & 46 \\
\hline \multicolumn{4}{|c|}{ Steps involving major metabolic pathways } \\
\hline F & Degradation of "stable" RNA & $\operatorname{srn} B$ & 67 \\
\hline R-Utrecht & DNA polymerase & pol & 165 \\
\hline $\mathbf{R}$ & Use of sucrose and lactose & scr, lac & $103 a$ \\
\hline \multicolumn{4}{|c|}{ Enzymes for restriction and modification } \\
\hline $\mathbf{R}\left(\mathrm{fl}^{+}\right)$ & $\mathbf{R} \cdot \mathbf{E c o} \cdot \mathbf{R} 1$ endonuclease & $\mathbf{R} 1$ & 100 \\
\hline P1 & P1 endonuclease & $\mathbf{P} 1$ & 174 \\
\hline $\mathrm{P} 1$ relative & Restriction system, IS & & 14 \\
\hline $\mathbf{R}(\mathrm{N}-3)$ & DNA methylase specific for cytosine & & 94 \\
\hline \multicolumn{4}{|c|}{ Functions associated with conjugation } \\
\hline $\mathbf{F}$ & Conjugal transmissibility & fer & \\
\hline $\mathbf{F}$ & Sensitivity to male-specific phages & pil & 191 \\
\hline $\mathbf{F}$ & Surface exclusion & eex & \\
\hline \multicolumn{4}{|l|}{ Miscellaneous } \\
\hline Col, R(i) & Colicinogeny & col & \\
\hline $\begin{array}{l}\text { P1, R(i) I-like } \\
\text { sex factors }\end{array}$ & Phage modification & $\bmod$ & \\
\hline $\mathbf{P}$ & Sensitivity to silicate & sil & \\
\hline$F$ and $R$ & Sodium dodecyl sulfate sensitivity & sds & 191 \\
\hline P-lac, $R(f)$ & Acridine sensitivity & acr & \\
\hline Hly & Alpha-hemolysin production & hly & \\
\hline Ent & Enterotoxin production & ent & \\
\hline K88 & K88 surface antigen production & $K 88$ & \\
\hline
\end{tabular}

${ }^{a}$ For an extensive compilation of genetic markers carried by plasmids, see reference 292.

faciens, $B$. anthracis, $B$. cereus, $B$. licheniformis, B. pumilus, B. subtilis, and $B$. thuringiensis. When examining Fig. 1 it is essential to recognize that only a few percent of the cell- to-cell transfers made possible by soil phages have probably been detected in this study. If all such pathways could be mapped, it seems inevitable that numerous genetic interconnections 
TABLE 6. Generalized transducing phages for members of the genus Bacillus

\begin{tabular}{lcc}
\hline \multicolumn{1}{c}{ Host } & Phage & Source \\
\hline B. amyloliquefaciens & SP-10 & 253 \\
B. anthracis & CP-51 & 253 \\
B. cereus & CP-51 & 253 \\
& CP-53 & 253 \\
B. licheniformis & SP-10 & 253 \\
& SP-15 & 253 \\
B. pumilus & PBS-1 & 253 \\
& PBP-1 & 157 \\
B. subtilis & SP-10 & 253 \\
& SP-15 & 253 \\
& PBS-1 & 253 \\
& S-1 & 253 \\
B. thuringiensis & Th-1 & 253 \\
& SP-15 & 253 \\
\hline
\end{tabular}

between the various cells would be convincingly demonstrated.

In view of these considerations, we contend that the "species" concept can no longer be meaningfully applied to members of the soil microflora. It is obvious that, at least in terms of the bacteria studied, no single organism can evolve in genetic isolation from other organisms with which it shares a common environment. Jones and Sneath (130) distinguish between a "taxospecies" (i.e., a species in the usual taxonomic sense) and a "genospecies," in which organisms are grouped because of their ability to interchange genes. In this context, it is possible that the genus Bacillus constitutes a single genospecies (214).

I attempted to construct a similar "genetic

8. pumilus

B. eoheericus

B. stearothermophilus

B. subtilis

B. lichonilormis

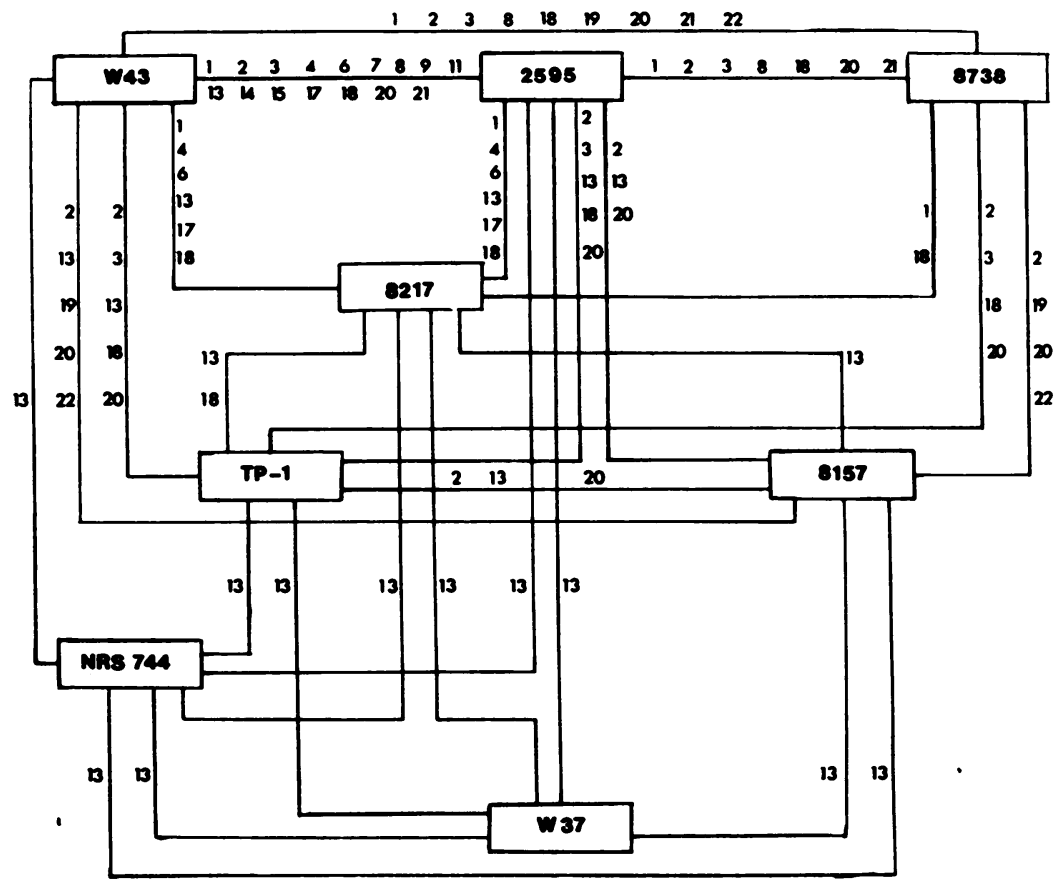

FIG. 1. Genetic "circuit diagram" showing pathways of cell-to-cell DNA exchange made possible by phages isolated on B. pumilus. Each number represents a distinct phage. Numbers inside boxes indicate the reference numbers for the bacterial strains used. Numbers on horizontal lines show DNA exchanges between members of the same species: numbers on vertical lines indicate possible interspecific transfers. This diagram merely maps the possibilities of successful lytic infection open to each of the phages listed. Some phages may be able to adsorb to cells and inject DNA without inducing a lytic cycle. A phage which lysogenized its host cell with $100 \%$ efficiency would not have been detected in this study. Further, each species listed appears to contain genes for a defective temperate phage (see text) which packages only cellular DNA. However, this phage has not been shown to be capable of transduction. Insofar as cellular and plasmid DNA may be able to move along the pathways shown in the heads of transducing phages, it must be remembered that this diagram merely indicates the organisms into which such DNA can penetrate. The fate of the DNA, once inside the cell, depends on the degree of nucleotide homology between donor and recipient cells and upon many other factors such as restriction-modification systems. However, interspecific transformation is possible within the genus Bacillus. Genetic markers from B. natto, B. niger, B. polymyxa, B. globigii, and B. licheniformis can be stably incorporated into the genome of $B$. subtilis by transformation (208); from Reanney and Teh (214). 
circuit diagram" for coliforms and other enteric bacteria, but the number of interlocking lines made this task unwieldy. It is obvious from Table 1 and from Novick (192) that at least 356 "different" ECEs can feed polynucleotide into $E$. coli. In some cases exact measurements of the DNA contents of these ECEs are not known, but from recorded molecular weights and contour lengths one can infer that the amount of DNA able to enter a coliform cell via its associated ECEs is equal to or greater than the DNA content of the cell's own genophore.

In the section, Genes Carried by ECEs, we set out the diversity of genes carried by various coliform ECEs. Thus, in the case of $E$. coli, because of the wide host ranges of conjugative plasmids and certain phages, specialized biochemical features not physically contained in the $E$. coli chromosome are mixed into the gene pool upon which selection acts. Figure 2 gives specific examples; genes for urease, lysine decarboxylase, phenylalanine deaminase, sulfite reductase, etc., are physically contained in the chromosomes of noncoliform enteric bacteria but can be passaged into $E$. coli by diverse ECEs. The general principle that emerges is that in any ecosystem where the microflora is connected by a sufficiently large number of ECEs, the size of the entity upon which selection acts may exceed by perhaps several orders of magnitude the size of the gene pool of a monoclonal population of bacteria propagated under laboratory conditions. It follows that, far from being "simple" or "primitive" organisms, bacteria are in fact an elegant adaptive answer to the changing stress patterns in different microenvironments. Because of ECEs, selection can maintain among bacteria a high degree of dispersed genetic variation at minimal metabolic cost while keeping cell genophores small enough to capitalize upon the advantages of a rapid rate of reproduction (210).

The genetic processes mediated by ECEs have been described in depth in recent reviews (see for example, references 218 and 219), so here I will confine the discussion to processes
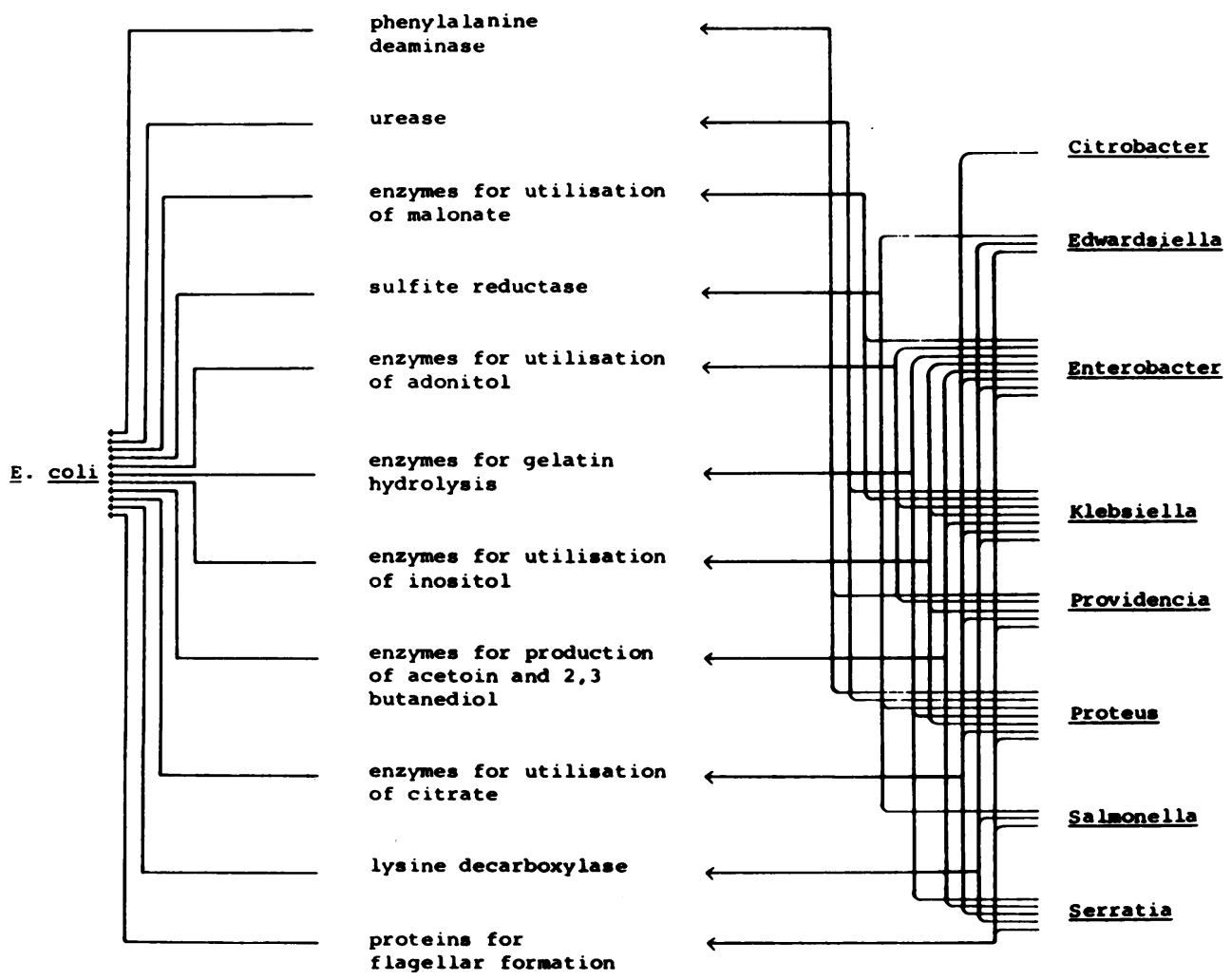

FIG. 2. Genes for a variety of proteins, not contained in the chromosomes of most $E$. coli strains, can enter a coliform cell from the reservoir species shown by means of viruses and plasmids. 
that illustrate the adaptive functions proposed for ECEs.

\section{GENETIC PROCESSES MEDIATED BY ECEs}

\section{Dissemination of Existing Genes}

Cell-to-ECE-to-cell gene transfer. The bestknown adaptive genetic process mediated by ECEs is probably the transfer of genes from cell to cell. The process of transduction, for example, has been massively documented in a number of bacterial species $(245,253)$.

The adaptive significance of transduction can perhaps be dramatized by considering what happens when P1 infects $E$. coli; one can describe the infection by saying it results in the destruction of the cell and the release of virus particles. But it would be as accurate to state that as a result of infection a fraction of the DNA of $E$. coli simply changes its state: the total genome of $E$. coli now exists in ecologically dispersed form among the population of progeny phages. I suggest that the genome of each prokaryotic species be envisaged as existing in two alternative conditions. In the most familiar examples a set of genes, physically linked into a continuous DNA molecule, constitutes the "chromosome" of the cell. In the alternative state these genes are maintained in ECEs and in reservoir species among the microflora that share, or have access to, the common environment. In this way, a balance may be achieved between stability and flexibility which maximizes the survival power of the ecosystem as a whole.

Phage conversion. Conversion phages have already been mentioned and some examples are given in Table 7. The case of the conversion phages in strains of salmonellae is illustrative; such phages bring about alterations in the chemical structure of the $O$ antigen polysaccharide. Phages $\mathrm{e}^{15}$ and $\mathrm{g}_{341}$ repress cellular transacetylation to galactose moieties on the polysaccharide (222). Phage $\mathrm{e}^{34}$ promotes the synthesis of two types of glucosyl transferase needed to link glucose to $\mathrm{C} 4$ of galactose $(32,223,269)$.

It is noteworthy that the conversion genes are expressed even in lysogenic bacteria in which all virus-encoded functions (other than the phage-specific repressor) are repressed (257). Various workers have expressed the view that conversion genes may derive from host chromosomes $(162,257)$. This hypothesis was tested by Matsuyama and Uetake (172), who mapped the chromosomal locations of the conversion phages in Salmonella anatum. They found that phages $\mathrm{e}^{15}$ and $\mathrm{g}_{341}$, both of which inhibit cellular transacetylation to galactose residues (above), map near the his locus (both prophages integrated between his and lys ). It is known that the structural gene (oafA) for transacetylase is located close to the his locus (167), as are other enzymes responsible for the synthesis of $O$ antigen polysaccharide (167).

Although these relationships are not conclusive, they do suggest that conversion genes may be formed from cellular DNA by a mechanism similar to that employed in the production of specialized transducing phages (172). If this thesis is valid and if it can be applied to other conversion genes, then phage conversion (like conjugative plasmid "conversion"; see reference 196) may represent a special case of transduction in which the fragment of cell DNA enters into a more permanent association with phage genes than is usual in most known transductions (see also reference 273).

TABLE 7. Some conversion and similar genes carried by phages

\begin{tabular}{|c|c|c|c|}
\hline Phage & Host & Function & Source \\
\hline $\begin{array}{l}\phi 105, \text { SP02 } \\
\beta\end{array}$ & $\begin{array}{l}\text { Bacillus subtilis } 168 \\
\text { Corynebacterium dipther- } \\
\text { iae }\end{array}$ & $\begin{array}{l}\text { Competence for transformation } \\
\text { Diptheria toxin }\end{array}$ & $\begin{array}{c}78 \\
81,171\end{array}$ \\
\hline $\begin{array}{l}\text { T4, T7, } \\
\text { lambda }\end{array}$ & Escherichia coli & $\begin{array}{l}\text { Association of DNA polymerase I } \\
\text { with membrane }\end{array}$ & 166 \\
\hline D3 & Pseudomonas aeruginosa & Surface antigen change(s) & 107 \\
\hline$e^{15}$ & Salmonella anatum & $\begin{array}{l}\text { Repression of gal transacetylation } \\
\text { synthesis of } \beta \text {-polymerase }\end{array}$ & 172 \\
\hline $\mathbf{e}^{34}$ & S. anatum & 2-Glucosyl transferases & 172 \\
\hline & S. anatum & Inhibition of gal transacetylation & 172 \\
\hline P22 (C1) & S. typhimurium & $\begin{array}{l}\text { Repression of L-arabinose isomer- } \\
\text { ase }\end{array}$ & 43 \\
\hline $\begin{array}{l}\text { Group A } \\
\text { phage(s) }\end{array}$ & Staphylococcus aureus & Leucocidin production & 260 \\
\hline $\begin{array}{l}\text { Group F } \\
\text { phage }(\mathbf{s})\end{array}$ & S. aureus & Staphylokinase production & 260 \\
\hline
\end{tabular}


ECE-to-cell-to-ECE gene transfer. Five different Salmonella phages carry genes responsible for the synthesis of $\mathrm{O}$ antigen polysaccharide (see Phage conversion). However, these viruses differ in host range and serological properties. This poses the question: How may genes be transferred between phages that lack a common host?

This problem was investigated by Uetake and Hagiwara (258), using phages $\mathrm{e}^{15}$ and $\mathrm{g}_{341}$. They showed that lysates from $S$. anatum cells mixedly infected with the two phages contained, besides parental phage, particles that carried one phage genome wrapped in the head and tail proteins of another phage in reciprocal combination. This phenotypic mixing (189) may occur rather frequently in situations in which generalized transduction is common. The DNA of $\mathrm{e}^{15}$ is a permuted collection of molecules similar to that found in P22 (255). In the situation described above, a "hybrid" phage with the DNA of one type and the host specificity of another may be formed by cutting the DNA of $\mathrm{e}^{15}$ into headful sizes characteristic of $\mathrm{g}_{341}(258)$.

Interactions among different ECEs illustrate the subtlety and flexibility of genetic response introduced into ecosystems by these elements. Prophages may themselves be transduced by other viruses (127). This provides another mechanism for bringing specific ECE genes into a cell normally insensitive to penetration by the ECE itself. Similarly, plasmids like F may be transduced in phage heads. This might have adaptive value in situations where genes carried by the plasmids confer a strong survival advantage but where successful matings occur rarely, if at all. A clear-cut example of this is found among gram-positive eubacteria; as noted in the section, The Ecology of ECEs, staphylococci lack conjugative plasmids, but the frequent cell-to-cell transfer of plasmids carrying resistance genes may be brought about by transducing phages (194). The Staphylococcus aureus phage $\mathrm{S} 1$, for example, transduces the nonconjugative tetracycline $\left(\mathrm{r}_{\mathrm{ms}}\right.$ tet $)$ plasmid (123). It seems significant that ECEs in staphylococci are transduced much more frequently than chromosomal genes (190). The reverse case-where phage DNA is carried in sexductive processes (see, for example, F'LAC $\mathrm{Mu}^{+}$episomes [169]) - might be favored in situations where successful matings were frequent in a population insensitive to a particular phage carrying a selectively useful gene or genes.

Although a great deal is now known about ECE genetics, novel interrelationships continue to be uncovered: the recent data of Schwesinger and Novick (229) suggest that the integration of a penicillinase plasmid in S. au- reus is promoted by prophage $\phi 11$. Inoue and Mitsuhashi (123) have shown that a tet resistance trait, originally carried in the $S$. aureus plasmid $\mathrm{r}_{\mathrm{ms}}$ tet, can become part of the genome of $S$. aureus phage S1. This may be considered a case of "phage conversion" where the conversion gene is derived from the DNA of an ECE rather than a cell. Experiments also indicate that a conjugative plasmid can mobilize an element that is not transmissible per se; for example, many $\mathbf{R}$ factors can mobilize the mercury resistance plasmid in $P$. aeruginosa PAT (see reference 242). Further interactions will undoubtedly emerge in the course of future research. In sum, one must conclude that the evolutionary plasticity of ECEs is enormous.

\section{Genome Sizing}

The ability of the cell to survive in a given environment often depends on the balance struck between the genetic load carried by the genophore and the rate at which the organism can reproduce; to be successful, the DNA of the cell must contain enough genes to meet the biochemical demands made by the environment, but at the same time it is useful for the cell to be able to replicate faster than competing organisms. Thus survival is often linked, through replicative rates, to genome size. I suggest that bacterial genomes can rapidly and effectively be sized by ECEs as stress conditions change. Lysogenization of a cell by phage may increase the size of the genome by as much as $2 \%$ in a single genetic event. Conversely, curing cells of transfer factors may reduce DNA contents. Since $30 \%$ of coliform DNA may consist of prophage (249), and since bacteria may contain up to $20 \%$ of their DNA in plasmid form (219), the degree of genome sizing possible by this means is considerable.

Agents like ethidium bromide used to cure or induce cells in the laboratory are unlikely to be those operating in nature. Natural mechanisms of the gain or loss of ECE's are likely to include ECEs themselves. Goldberg and Bryan (84) have shown that inactivation of defective phage PBSX can cause Bacillus subtilis to acquire sensitivity to SP-10 infection. Infection of coliforms with phage M13 cures the cells of the $F^{1}$ factor (204).

\section{Controlled Randomization of Genomes}

IS elements and phage Mu. IS elements and phage $\mathrm{Mu}$ are discussed in detail in the section, Natural genetic engineering. Although IS elements are naked DNA molecules, whereas $\mathrm{Mu}$ is a phage, both types of ECE have similar genetic properties. Mu, for example, causes mutations in the genome of $E$. coli on an apparently random basis. Even within a single 
gene such as lacZ, there appears to be no bias towards any one site (38).

At first sight the random mutations caused by $\mathrm{Mu}$ and IS elements seem formally analogous to entropic mutations. However $\mathrm{Mu}$ - and IS-induced mutations cannot be entropic in the sense defined, because the ecological abundance and cell specificity of a phage such as $\mathbf{M u}$ is sensitive to selective pressures. Further, $\mathrm{Mu}$ and IS elements do not cause mutations by changing preexisting sequences: rather they work by inserting their own DNA into the continuity of the chromosome of the host. The prime adaptive advantage of this insertion is discussed in the section, Natural genetic engineering. At this point, we merely note that random mutations due to the insertion of "foreign" DNA will have genetic effects different from modulated mutations due to mutagenic polymerases. For example, insertion of a fixed length of DNA between two previously contiguous structural genes will alter gene spacing and hence affect transcriptional timing. Paradoxically, the insertion of $\mathrm{Mu}$ often has the effect of deleting DNA (112). Such deletions may group genes into novel combinations by removing the intervening sequences (see, for example, reference 129). Because of its capacity to insert and delete DNA, Mu will function in fine-scale genome sizing.

Permuted phage genomes. The DNAs of phages T2, P22, etc., are circularly permuted and terminally redundant. This means that, from a single genetic particle, an extremely broad spectrum of different sequences is recreated with each lytic cycle, thereby exposing to the test of selection as many gene permutations as the burst size of the cell and the total population number of progeny phages permits. If the order in which genes enter the cells affects phage survival and/or if position effects are important in promoting effective replication, then it follows that any individual permutation will not be exactly equivalent to any other in terms of its functional fitness. This idea would be partly invalidated if the DNA cyclized via its redundant termini, but available evidence (66) seems incompatible with the existence of a circular replicating intermediate for T4. Thus, we suggest that the random withdrawal of genes into phage heads provides a unique example of programmed variation, i.e., of the way novelty of genetic organization may be continuously replenished within a monoclonal population.

\section{Natural Genetic Engineering}

The term "genetic engineering" is normally applied only to the laboratory manipulations by which DNAs from taxonomically divergent sources are fused into new combinations by restriction and ligating enzymes.

Restriction enzymes are normally considered to serve a defensive function in that they protect the cell against foreign DNA. At first glance, enzymes of this type thus appear to constitute a major barrier to extensive interactions among heterologous nucleic acids. It is paradoxical that it is precisely this class of enzymes that has made genetic engineering possible in vitro. The question thus arises as to whether, under suitable selective pressures, restriction enzymes might also facilitate the emergence of novel gene combinations in nature.

In this section we will interpret the term "genetic engineering" in its broadest sense to mean any natural process(es) of polynucleotide exchange that may be achieved by enzymes normally resident in living cells or introduced into them by ECEs. As such, the term encompasses all forms of genetic recombination; indeed, the familiar mechanism of eukaryotic sexual recombination may be regarded as one of the most successful forms of genetic engineering "invented" during evolution. In this article, however, I am concerned only with the older and, I believe, still more widespread processes of genetic engineering that are mediated by ECEs.

Processes of polynucleotide exchange involving resident homology. The thesis put forward here demands (i) that all forms of life contain enzymes capable of mediating specific processes of polynucleotide exchange, and (ii) that all natural DNAs possess stable, preferred sites for such exchange, although "illegitimate" interchanges may still occur during the coupled processes of DNA replication-repair-recombination.

This concept rests on a broad factual base: all known replicons, from the 0.75 -kilobase-long IS1 element to eukaryotic cells, contain or use a specific recombinational machinery. The exact molecular mechanism(s) of recombination is still debated (see reference 110). Molecules involved include denaturation protein(s), sequence-specific endonucleases, exonucleases, repair enzymes such as polymerase I, and ligating enzymes. Considerable interest attaches to the restriction enzymes (175), which are known to be encoded by ECEs; perhaps the best known is the restriction endonuclease $R \cdot E c o \cdot R 1(100)$ specified by the $E$. coli $\mathrm{fi}^{+} \mathbf{R}$ factor. Endonuclease $\mathrm{P} 1$ is found only in $E$. coli lysogenic for phage P1 (174). Restriction system 15 is determined by an ECE related to P1 (14). Kerszman et al. (135) have suggested that a further nuclease specificity in $E$. coli $\mathrm{W}$ is determined by 
a temperate phage (for review of restrictionmodification systems, see reference 13).

The specificity of any restriction endonucleolytic cut is exacting and provides powerful evidence for the contention that many processes of DNA exchange are "quantized" in the sense that only the units intervening between specific targets may be transferred.

The substrate for $R \cdot E c o \cdot R 1$ is (100):

\section{5' A/TG ( $\downarrow)$ AATTCT/A 3' \\ 3' T/ACTTAA ( $\uparrow)$ GA/T 5'}

This sequence possesses a twofold rotational symmetry about an axis perpendicular to the axis of the double helix. Cleavage by $R \cdot E c o \cdot R 1$ produces cohesive termini of four nucleotides, which provide for interdigitation with any other DNA possessing the same restriction target. One cannot help but notice that symmetry elements of this type characterize many of the control loci sequenced to date in coliforms, e.g., the lac operator region (80). Further, such symmetrical elements (palindromes) are universally distributed throughout eukaryotic chromosomes (265). Such observations sustain the thesis that selection acts to maximize recombination between common DNA "markers" (probably repeated DNA sequences) spaced so as to preserve the functional integrity of genes and operons in processes of DNA exchange. The repetitious nature of the base sequences in such markers might be expected to facilitate recombinational processes. Recombinational "hot spots" are documented at many loci in most chromosomes (see, for example reference 82 and the section of this article, Polynucleotide exchange involving nonresident homology).

It is perhaps worthwhile noting that whereas R1 specific cleavage generates fragments that can reassociate with either polarity, $R 11$ cleavage generates fragments that can only reassociate with native polarity (13). Arber (13) suggests that the A-T pair in the symmetry axis of the R11 cleavage site might have "its more profound meaning" in the repair of cleaved DNA. One can go on to ask whether this preservation of correct polarity is also useful in the in vivo linking of genetic material from different sources.

Targets for $\mathbf{R} \cdot \mathrm{Eco} \cdot \mathbf{R} 1$ are found on the small plasmid pSC101 (50), on phage $\lambda$ DNA (7), on DNA from the mammalian virus SV40 (173, 181 ), and on amphibian DNA coding for ribosomal RNA (182). In view of the small size of the target sequence, its widespread distribution may be entirely governed by chance. However, the possibility remains that targets at particularly disadvantageous positions may be elimi- nated by selective pressures. The feasibility of "genetic engineering" using restriction enzymes has been abundantly demonstrated by recent studies. Cohen and Chang (50) inserted a DNA fragment into the single $\mathrm{R} \cdot \mathrm{Eco} \cdot \mathrm{R} 1$ site on pSC101; neither the Tet resistance phenotype nor the ability of the plasmid to replicate was abolished, and the recombinant DNA was able to transform $E$. coli. It is important to note that, unless illegitimate recombination occurs, annealing of cleaved restriction targets from different DNAs regenerates the target sequence and thus preserves in the recombinant genome the functionally "quantized" character exhibited by the parental DNAs.

In such manipulations $(50,186)$, the choice of DNAs and test conditions was made by the scientists to suit the purposes of each particular experiment. In natural ecosystems, the choice of DNAs will be determined by selective pressure and will often involve chromosomal DNA targets on the one hand and ECE targets on the other. However, both experiments show that biologically active ECEs may result from the use of restriction endonucleases and ligating enzymes known to be present in cells. The more general thesis, that genomes are organized into functional "quanta" separated by recombination-prone targets, is very strongly supported by the recent study of Botstein and Herskowitz (30). These workers constructed hybrids between Salmonella phage P22 and coliphage $\lambda$. The significance of their study lay in the fact that, despite certain similarities such as a similar grouping of functions in both genetic maps, P22 and $\lambda$ are quite different. The DNA of P22 for example is circularly permuted and terminally repetitious, whereas that of $\lambda$ is unique and terminally cohesive due to $5^{\prime}$ ends of overlapping complementarity. Botstein and Herskowitz constructed a recombinant phage $(\lambda$ immP22) in which $\lambda$ DNA in the region from the left of gene $\mathrm{N}$ to a point beyond $\mathrm{P}$ was substituted by a functionally analogous P22 segment (30). $\lambda$ immP22 was apparently formed by phage-specified or bacterial recombination rather than by "illegitimate" recombination. The conclusions of Botstein and Herskowitz (30) are worth quoting: "evolution of the lambdoid phages appears to have proceeded within regions of function which have been selected for the ability to form viable combinations with functional segments from other members of the lambdoid phage group." Later, "we suggest that evolution proceeds by diversification within segments encoding particular functions: each segment retains functional compatibility and recombinational homology so that reassortment between them is easy and frequent" [ital- 
ics mine]. An almost identical conclusion was reached by Szybalski and Szybalski (249), who, after an extensive study of phage $\lambda$ genetics, postulated a "modular" organization of both phage and host DNAs so as to facilitate a frequent exchange of parts between the two.

It is important to note that our thesis does not imply that restriction target sites are the major "hot spots" for recombinational exchange. All models of eukaryote chromosome organization $(55,261)$ and of DNA replication in eukaryotes (124) propose that specific control sequences will be repeated many times along chromosomes. The models of Ioannou (124) and Bonner and Wu (27), irrespective of their validity in other respects, are probably correct in assuming that short DNA sequences (origin sites for replication, spacing elements, promotor signals, etc.) will (i) be dispersed throughout chromosomes outside coding regions, and (ii) in many cases possess identical base sequences. If this identity of sequence extends across species "barriers," it seems unlikely that selection would bypass such ready-made homology in promoting processes of DNA exchange.

Before leaving this section, it may be useful to sound a note of caution concerning the need for sequence "homology" in recombination. Plasmids with common sequences of substantial length can coexist without detectable recombination in Staphylococcus aureus (195). Conversely, genetic regions totally lacking in homology can participate in extremely precise crossover events. Perhaps the best-studied example of this is the integration of phage $\lambda$ into the chromosome of $E$. coli. In this instance, insertion of the episome is catalyzed by an "integrase" enzyme (235), which selectively recognizes the $a t t B$ locus on the coliform chromosome and the att $P$ locus on the $\lambda$ genome. Excision of $\lambda$ DNA requires the int and $x i s$ gene products. Such a highly sophisticated system for the interaction of heterologous DNAs restricts the crossover event to a specific site. Precisely because of this specificity, as Richmond and Wiedeman (219) have noted, the adaptive potential of $\lambda$ may be limited.

A further interesting feature of $\lambda$ recombination is the involvement of the red enzymes (105), which catalyze generalized recombination between $\lambda$ genomes. Only further research will determine whether such specialized mechanisms are frequent or rare in nature. In the absence of data to the contrary, I will, in this article, continue to assume that recombination between interacting polynucleotides is facilitated by the presence of common nucleotide sequences.

Polynucleotide exchange involving nonresi- dent homology. Recombination between "modules" in taxonomically distinct groups occurs via target sequences permanently resident in the DNAs of cells and ECEs. In $E$. coli such genetic exchanges usually involve the recA system.

A highly significant finding in recent years has been the discovery of elements that mediate recombination in a nonspecific way; such recombination may be $\operatorname{rec} A$ independent and illegitimate. The best-studied agents of this type may belong to the IS class: Fiandt et al. (74) and Starlinger and Saedler (243) found that strongly polar mutations in $E$. coli arise because of the insertion of "foreign" DNA. As measured in base pairs, these foreign sequences are quite short: IS1, about 750; IS2, 1,300; IS3, 1,300 ; and IS4, 1,400 (see reference 116). IS elements can insert at various positions in the chromosome and with either orientation. Frequently, they consist of inverted repetitions, although Ptashne and Cohen (207) have identified IS1 as a direct tandem duplication.

The mutator phage $\mathbf{M u}$ described by Taylor (250) has properties remarkably similar to those of IS agents (see references 28, 37, and 38; for review, see reference 113), despite the fact that $\mathrm{Mu}$ contains much more DNA. Phages can be described as "plasmids which have found another way of getting around." If IS-type elements are important in evolution (see below), then it is not surprising that the eminently successful phage mode of cell-to-cell dissemination has been exploited to spread IS-type DNA.

The potential importance of IS elements has become increasingly evident as their occurrence and positions in various DNAs have been mapped by heteroduplex techniques. Saedler and Heiss (226) showed that the chromosome of $E$. coli K-12 contains about eight copies of IS1 and about five copies of IS2. Significantly, IS2 was also found on the F plasmid. (However, the claim that IS1 occurs on F has since been withdrawn [115].) Other studies have indicated that such sequences are widely distributed in cell and ECE DNAs: IS1 can be detected in polar mutants of phage $\lambda$ (74); IS1 and IS2 occur on plasmids R6, R6-5, and R100-1, whereas IS1 also occurs on R1 (115); IS3 occurs on R6 and R6-5 (207). The map positions of these elements strongly suggest that they function in recombination events. It had previously been found (59) that specific segments of F were "hot spots" for Hfr formation. The first such "hot spot" has been identified as IS2 (115), and the second has been identified as IS3 (116). Various F' plasmids have been shown to have structures consistent with the view that their parental $\mathrm{Hfr}$ cells were formed by reciprocal recombination 
between IS element(s) on the $F$ plasmid and identical IS element(s) on the chromosome of the F-containing parent of the Hfr strain (114116).

It now seems virtually certain that IS elements play a basic role in adaptation: the insertion of IS sequences into interacting polynucleotides makes recombination possible between DNA molecules totally lacking in resident homology. It would not be inappropriate to regard IS elements as "transmissible recombination targets." Recent data indicate that (i) IS-type entities are ubiquitous in bacterial populations and (ii) such sequences can be translocated from one chromosomal locus to another andby inference - from one cell to another. IS entities have been described as the most "promiscuous" of all ECEs (219).

The flexibility introduced into adaptive processes by IS-type DNA may be illustrated by considering the evolution of drug resistance in enteric bacteria.

Evolution of $\mathbf{R}$ factors in bacteria. A characteristic genetic feature of most $R$ factors is the presence of genes coding for proteins that inactivate antibiotics. The origin of such genes has not been unequivocally determined, but Benveniste and Davies (21) have shown that the antibiotic-modifying enzymes of certain $A c$ tinomycetes species are similar to those responsible for plasmid-mediated drug resistance. The presence of such enzymes might be of permanent selective advantage to a soil organism. No known plasmid can infect both enteric bacteria and Actinomycetes, but the transfer of genes between such taxonomically distant genera may have been accomplished by using intervening species in a "stepping stone" manner (130). If soil Actinomycetes do constitute the ancestral resevoir for resistance genes, then the contemporary presence of these genes in so many diverse species inhabiting different ecosystems points to a widespread process of gene dissemination in nature.

In this context it is useful to examine the specific example of the penicillinase-TEM $\beta$ lactamase - in the light of recent data. Hedges et al. (97) found that the TEM protein was similar in a wide variety of naturally occurring plasmids, irrespective of the species of origin or the geographical source of the $R$ factor (see reference 102). These data strongly suggest that (i) the TEM gene for all these $\mathbf{R}$ factors had a common origin and hence (ii) this gene must be able to migrate among heterologous DNAs.

Resistance genes with this ability have now been discovered. Hedges and Jacob (98) showed that the ampicillin resistance gene on plasmid
RP4 could be acquired by other plasmids resident in $E$. coli. Thus the TEM gene must be carried by a DNA molecule capable of ready translocation from one replicon to another (see reference 228). This molecule has been identified as a $3 \times 10^{6}$-dalton sequence on the plasmid, and the transposable unit has been termed TnA. A list of such "transposons" (98) now includes sequences coding for tetracycline resistance (143), kanamycin resistance (24), and joint resistance to streptomycin and trimethoprim (99).

What is the molecular mechanism of translocation? The gene for transposable tetracycline resistance is flanked on either side by inverted DNA repeats $(143,234)$. Ptashne and Cohen (207) have shown that these sequences are homologous with IS3. Similarly, Heffron and coworkers (101) have established that $\operatorname{Tn} A$ is bounded by inverted repeat sequences, although these appear to be much shorter than known IS elements. Heffron et al. (101) suggest that inverted repeat sequences flanking transposable genes may be specific recognition sites for enzymes used in excision and integration. It is pertinent to note that the translocation of TnA, like that of IS elements, is independent of the $E$. coli recA system (see reference 101). A possible reason for the inverted character of these IS-type sequences may be that normal host-mediated recombination between inverted and repeated sequences reverses but does not excise the intervening sequence (121). According to this view, recombination between tandemly repeated sequences might be disadvantageous because it could result in the loss by excision of a possibly vital resistance gene. Also, inversion of one segment of a duplicated region after integration of ECE DNA traps the episome in the integrated state (4).

TnA was found to insert at a minimum of 12 distinct sites in the plasmid RSF1010 (101). The sites of insertion did not appear to be random and were restricted to one-third of the RSF1010 molecule. If, however, the insertion of $\operatorname{TnA}$ is site specific, the target sequence must be short and hence rather common (101).

In summary, it appears as though (inverted) repeat (IS-type) sequences have played a crucial role in the coupled evolution of bacteria and their plasmids. Some idea of the potential versatility they engender is given by Fig. 3 (from Ptashne and Cohen [207]), which outlines a plausible scheme for the reversible dissociation of RTF and R determinants and for the continuing amplification of resistance determinants.

Significance of sequence duplication in natural genetic engineering. Tandem duplications 


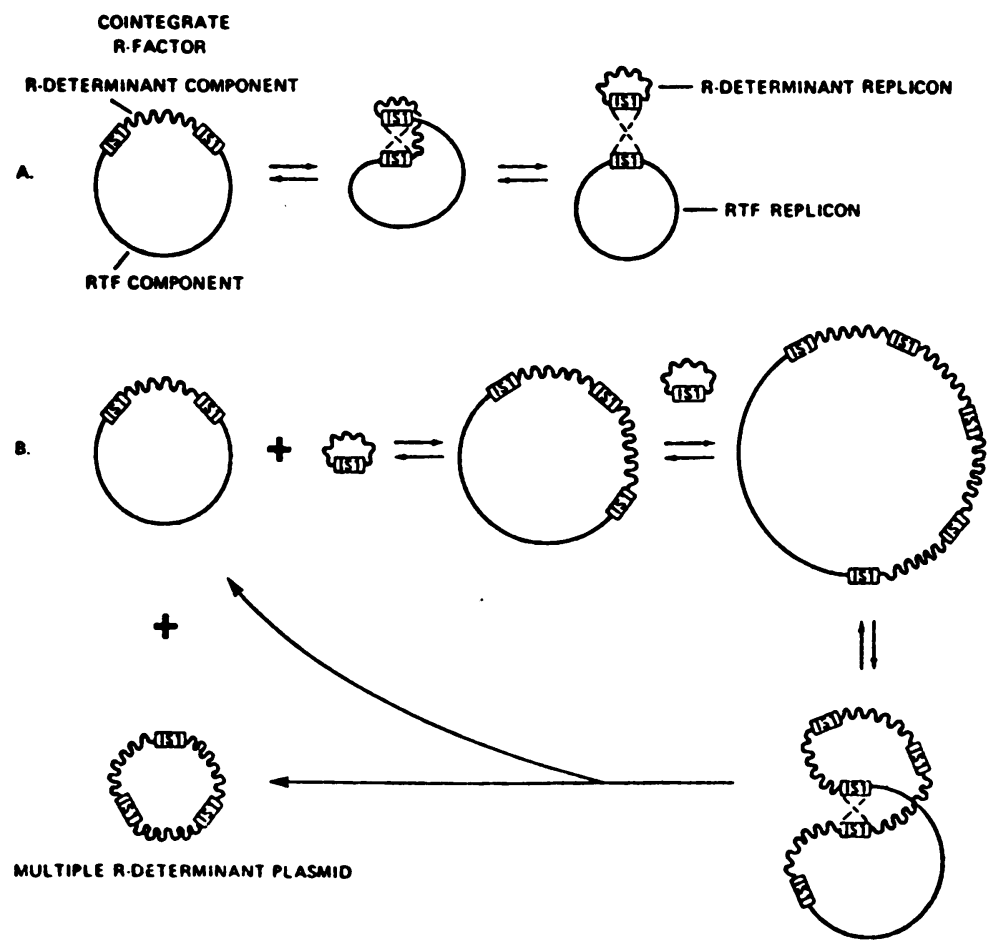

Fig. 3. Genetic versatility made possible by IS-type elements. This figure shows a possible mechanism for the formation of complex plasmids and for the amplification of resistance determinants (from Ptashne and Cohen, 1975).

are known to facilitate recombination (197). By the same token (illegitimate) recombination may facilitate duplication (249). In view of the universal distribution of recombinational systems, I propose that sequence reiterations represent the most common type of programmed mutation. The experimental evidence of Jackson and Yanofsky (125) suggests that "spontaneous" gene duplications may arise in bacteria almost as frequently as gene mutations. This is highly significant in view of the fact that the duplication of a sequence 1,000 or so nucleotides long (the calculated size for an average gene) is a much more complex event than a point mutation. The data of Rigby et al. (221) confirm that gene duplication is a primary - and frequent event in the evolution of bacterial enzymes with novel specificities. Apparently the most genetically facile response to low concentrations of utilizable substrate molecules is the hyperproduction of enzymes whose active sites fortuitously possess a slight affinity for readily available compounds of related chemical structure (see, for example, reference 103).

Adaptive responses of this nature also occur in eukaryotes. Hansche (91) has demonstrated that Saccharomyces cerevisiae can adapt to the presence of an unsuitable substrate ( $\beta$-glycerophosphate) by duplicating the gene for its general acid monophosphatase.

Sequence reiterations are not restricted to genes. The repeated character of IS elements and their multiple occurrence on certain DNAs suggest that specific short-sequence elements may readily undergo duplication. Repetitious DNA, which does not appear to code for protein, is a basic and characteristic feature of eukaryotic chromosomes. Such sequence reiterations are believed to have played a crucial role in the evolution of higher cells (33).

Some indication of the importance and plasticity of sequence reiteration may be gained from studies on the frequency of duplication in systems mutant in their normal recombinational mechanism(s). In a study of tandem duplications in phage $\lambda$, Emmons et al. (71) showed that frequent duplications could be detected in a deletion phage such as Tdel33, which is red $^{-}$and int $^{-}$. Such duplications probably result from "illegitimate" recombinations (77). An apparently paradoxical feature of such recombinations, in terms of our concept of pro- 
grammed mutations, is the finding of Straus (247) that four different mutagens increase the frequency of tandem gene duplications in the glyS region of the coliform chromosome. If programmed variation occurs, randomly acting mutagens should decrease the frequency of the exact duplications which I have postulated to result from normal enzyme function(s).

This paradox may be resolved by recalling that, in the absence of ECEs and stress conditions, selection probably acts stringently to conserve the genetic structure of specific genophores. Thus there may exist in unstressed cells some mechanisms to limit or abolish the sequence duplications that might, if permitted to proceed unchecked, impair the survival competence of the organism. Entropic or modulated mutations in the genes responsible for these mechanisms might be expected to increase the frequency of detectable duplications.

In assessing possible relationships between recombinational events and ECEs, it is essential to recall that any tandem duplication can create a circular DNA by reciprocal crossover (191). By reversing this process it follows that integration of such a DNA may generate duplications. Duplications may be frequently involved in the creation of ECEs. The pi factors described by Ames et al. (8) are characterized by a reduplication of the his operon except for gene $\mathrm{G}$, and attachment of the reiterated (pi) element to a cryptic ECE to give a composite pifactor. Stodolsky (246) has shown that recipient genes are duplicated during generalized transduction; models proposed to explain these duplications suggested crossovers during replication (246). An almost inevitable involvement of duplication in the creation of episomes is suggested by the modular nature of $R$ factors. Presumably the resistance genes were created by duplication; otherwise, gene pickup by the resistance transfer factor would delete such genes from the donor chromosome (209). In general terms, the creation of an "extra" gene is an a priori requirement for ECE construction if the donor population is not to be disadvantaged through loss of information.

Universality and frequency of natural genetic engineering. The continual emergence of new combinations of drug resistance suggests that adaptations of this type occur with increasing frequency as drug usage rises (10). An R factor consists of an independent (RTF) replicon and its associated resistance genes. Figure 3 shows how the processes of natural genetic engineering described in this section can (i) increase or diminish the molecular weight of the plasmid, (ii) provide for the addition of new resistance genes, (iii) segregate the replicon from the resistance determinants in a flexible fashion, and (iv) provide for the ready rearrangement of nucleotide sequences within the one plasmid DNA molecule.

The temptation to generalize from this example is irresistable: if all the multitudinous genes in an ecosystem can enter into reversible associations with transmissible ECE DNA by the mechanisms described, then it is clear that evolution largely proceeds through a continuing process of ECE-mediated genetic "experimenting," which enables almost any "desired" innovation to be mobilized in response to selective pressures. It is hard to believe that so powerful an adaptive device is restricted to unicellular organisms. The "control element" described by McClintock (163) in maize has many of the properties ascribed to IS elements (for review, see reference 76 ).

Heteroduplex mapping techniques provide some clues as to the nature and frequency of the genetic events involved in the creation of known replicons. The plasmid derivativeF14 - contains the entire F sequence (94.5 kilobases) and 211 kilobases of chromosomal DNA; in addition, F14 contains a repeat of a particular F sequence element (200). This structure was almost certainly created by some form of natural genetic engineering. The population of F14 molecules was found to contain molecules the size of $\mathrm{F}$ and others 2.3 times this value in both rec $A^{-}$and rec $A^{+}$cells. Ohtsubo et al. (200) propose that this heterogeneity was caused by an intramolecular recombination made possible by the duplicated sequences. In a related study, Lee et al. (152) found that F'ilv episomes derived from F14 by P1-mediated transduction consisted predominantly of deletions, although a particular molecule (F316) contained a small insertion of unknown origin. There appeared to be preferred sites (hot spots) for deletions (152).

Although other examples could have been chosen, this particular set of experiments, by revealing insertions, deletions, duplications, ECE-host DNA fusions, transductive processes, etc., within a limited group of conjugative coliform plasmids and their derivatives, suggests the ubiquity and frequency of recombinational processes in the evolution of prokaryotes and their ECEs.

Turning to eukaryotes, a suggestive series of studies have been performed on SV40 virus: Serial undiluted passage of SV40 through host cells results in rearrangements of the viral genome (34). These may arise from the introduction (by recombination) of host cell DNA (150) and by the loss of some segments of the viral genome and the amplification of others. Khoury et al. (136) have recently reported that 
a defective SV40 (DAR) has only one R Eeo $\cdot R 1$ target site, whereas after four serial passages of infectious DAR at high virus/cell ratios the predominant viral species possesses three such targets. Two discrete viral DNA regions appear to exist in this novel species, representing onethird of the original genome size. The variant molecule is believed to have arisen by two specific recombination events followed by reiteration of the conserved segment $(136,60)$.

These and related studies convincingly sustain the view that ECE genomes under stress can exploit an extraordinary plasticity of recombinational sites and enzymes in their adaptive processes.

\section{Miscellaneous}

The ECE-induced effects discussed to date have resulted in genetic modifications that are actually or potentially permanent. However, certain phage-cell symbioses may never attain genetic stability. An illustrative example is the relationship between Shigella dysenteriae and phage T7. Li et al. (153) showed that lactosenegative strains of $S$. dysenteriae formed red colonies on MacConkey agar when the bacteria were infected with $\mathrm{T} 7$, indicating that lactose was being utilized by the organism. Investigation showed that $S$. dysenteriae carries the gene $\mathrm{Z}$ ( $\beta$ galactosidase) but lacks gene $\mathrm{Y}$ which controls the permease function responsible for entry of lactose into the cell. Infection with T7 results in the production of a phage-specific enzyme(s), probably lysozyme and $N$-acetylmuramyl-L-alanine amidase and that this activity converts the bacteria into osmotically sensitive cells. In such $S$. dysenteriae. T7 clones, small molecules like lactose can diffuse in and large molecules like $\beta$-galactosidase can leak out. Such clones are surprisingly stable. $\mathrm{Li}$ et al. (153) reported that $\mathrm{lac}^{+}$colonies could still be obtained after 57 single-colony isolations and restreakings (18). Similar results have been reported for Proteus (49) and for Brucella (131).

These data show that even a lytic ECE can, under certain conditions, confer survival advantages on the host organism.

\section{OTHER EVIDENCE FOR PROCESSES OF ECE-MEDIATED POLYNUCLEOTIDE EXCHANGE}

\section{Dispersed State of Specific (Plant) Proteins}

Angiosperms are divided into monocotyledons and dicotyledons: Harbourne (93) has listed various flavonoid compounds that occur in both classes; for example, the rare isoflavones occur in the widely separated Iridaceae (monocot) and Leguminosae (dicot). As the isoflavones require an unusual, distinctive biosynthetic pathway, it seems unlikely that parallel evolution in the two groups can explain this common metabolic process. Viruses are known which infect these divergent groups, so that modular gene transfer seems a more credible explanation than the creation, by independent, successive mutations, of identical pathways in distinct organisms.

A similar situation arises with iridoid compounds. Bate-Smith and Swain (19) note that such molecules as asperuloside and aucubin occur sporadically in diverse plant groups (Table 8). Again, virus-mediated gene transfer can more plausibly explain this scattered pattern than the unlikely alternative postulate of multiple, convergent evolutions. Kjaer (142) points out that families with no obvious systematic connections provide consistent sources of thioglucosides. A number of isolated species from widely differing families (e.g. Euphorbiaceae, Phytolacaceae, and Plantaginaceae) produce thioglucosides. Kjaer comments: "in these cases it has been reported that quite closely related species are often devoid of glucosides and no explanation, other than parallelism or convergence, can be offered for these sporadic occurrences."

These data suggest that systematic survey of the viruses known to infect the various groupings listed might be rewarding.

\section{"Simultaneous" Appearance of Similar Genes in Unrelated Organisms}

The fossil record shows that many diverse phyla of animals with skeletons evolved from soft-bodied ancestors within a rather short time span (100 million years). Mourant (183) has

TABLE 8. Sporadic distribution of asperuloside and aucubin

\begin{tabular}{|c|c|}
\hline Asperuloside & Aucubin \\
\hline Rubiaceae & Cornaceae \\
\hline \multirow[t]{2}{*}{$\begin{array}{l}\text { Escallonia (Saxifragaceae) } \\
\text { Daphniphyllum } \\
\quad \text { (Euphorbiaceae) }\end{array}$} & $\begin{array}{l}\text { Scrophulariaceae } \\
\text { Orobanchaceae } \\
\text { Lentibulariaceae } \\
\text { Globulariaceae }\end{array}$ \\
\hline & Plantaginaceae \\
\hline $\begin{array}{l}\text { Fouquieria (Fouquieriaceae) } \\
\text { (Asperocotillin) }\end{array}$ & $\begin{array}{l}\text { Buddleia } \\
\text { (Loganiaceae) } \\
\text { Garrya (Garryaceae) } \\
\text { Eucommia } \\
\text { (Eucommiaceae) } \\
\text { Hippuris } \\
\text { (Hippuridaceae) }\end{array}$ \\
\hline
\end{tabular}


suggested that the gene for alkaline phosphatase, which is associated with the deposition of skeletal phosphate, was the result of a "highly improbable mutation." He goes on: "I suggest that, having once proved successful and presumably spread to the whole of the species in which it first occurred, the mutation continued to spread to virtually the whole of the metazoa and parazoa by means of transduction" (183).

\section{PROCESSES OF POLYNUCLEOTIDE EXCHANGE AMONG EUKARYOTES}

So far, I have largely confined the discussion to prokaryotic ECEs. When extrapolating to higher organisms, a little thought suggests that an authentic analogy can be drawn between the involvement of ECEs in processes of cell adaptation among bacterial populations and their involvement in the processes of morphogenesis and differentiation among the population of cells in a metazoan organism during development. This thesis is rendered more credible by considerations of early metazoan evolution. It is generally accepted that metazoa arose from free-living cells. However, the advantages of ECE-mediated nucleic acid transfer discussed in relation to bacteria make it likely that some mechanism of polynucleotide exchange existed in these first metazoan cells. This being so, it is difficult to believe that selection would bypass this process entirely in the further evolution of multicellularity. Indeed, it is not easy to see how a primitive cell colony not differentiated into somatic and germinal tissues could evolve into a coordinated system unless some mechanism existed to ensure that an advantageous change introduced into the genome of one cell could be amplified and transmitted to other cells, thereby maintaining the genetic homogeneity of the organism (211). Some reasons why this mechanism may have involved RNA and not DNA have been summarized by Temin (251) in an extension of his protovirus hypothesis: with RNA, DNA deletions are not necessary to create transposable information. Also, gene duplications are relatively easy because one can dispense with an excision mechanism.

In the remaining sections of this article I briefly review possible roles for ECEs in the development and adaptation of higher organisms. Much less data are available in this area than in the field of bacterial genetics; further, certain observations which are sometimes deployed as support for various theories have yet to be convincingly confirmed. In this sense, therefore, extension of the argument to eukaryotes is injudicious at this time. However, some intriguing proposals have been aired. On bal- ance, it seems useful to present these ideas provided the reader is aware of their speculative nature.

\section{POSSIBLE INVOLVEMENT OF ECES (RNA TUMOR VIRUSES) IN EMBRYOGENESIS}

A number of theories $(82,118,119,209,211$, 251) have proposed that type C RNA tumor viruses play a role in the normal development of higher animals. Certain broad lines of experimental evidence are consistent with this general concept: (i) the DNA of type $\mathrm{C}$ viruses appears to exist endogenously in all vertebrate cells (119); (ii) both the gs antigen and RNA specific to type $\mathrm{C}$ virus genomes can be detected in the embryonic cells of uninfected animals $(96,206)$; and (iii) tissues having a high proliferative activity-like embryonic cells-transcribe type C "virus" DNA to a much greater extent than tissues with lower mitotic figures (185).

Solter et al. (239) have found numerous RNA tumor virus-like particles during various stages in the development of mouse embryos. All embryos examined contained these entities. The observations that these particles were never observed in unfertilized eggs and zygotes, and were present in substantial numbers in the 2 to 8 cell stages and in much diminished concentration at the blastocyst stage are consistent with the concept that the release of these entities is genetically programmed. The fact that these entities contain lipoprotein membranes is interesting in the context of a paper by Artzt and Bennet (15). These workers studied the surface structures in embryo tissue by using as a model system a primitive teratomic clone trapped at a specific developmental step. Antiserum prepared against this uncommitted clone reacted with sperm cells and with normal cleavage stage embryos but not with adult somatic cells. Expression of this antigen was low in the one-celled embryo, increased to a maximum at about eight cells, then declined again; there is thus a rather striking correlation between the level of this antigen in early cleavage tissue and the frequency of the virus-like entities noted by Solter's group at similar stages of development. It is unlikely that virus-like entities at this early stage in ontogeny would function as agents of cell differentiation. Solter et al. (239) have produced evidence that these entities act to stimulate RNA production.

A specialized embryonic element in which RNA tumor virus-like entities have frequently been observed is the placenta. Type $\mathrm{C}$ particles, which appeared to be endogenously derived, have been noted in the placental villi of ba- 
boons (134) and of humans (133). Similar particles have been found in near-term placentas of cottontop marmoset monkeys (231). Feldman (73) has described type $\mathrm{C}$ particles budding from syncytial trophoblasts, pericytes, Hofbauer cells, and mesenchyme in Rhesus monkey placentas. She also found smaller entities measuring $30 \mathrm{~nm}$ in diameter budding from the cytotrophoblastic cell column and decidual basalis. These observations have recently been extended from primates to lower mammalian orders by the discovery of type $\mathrm{C}$ particles in rat placentas (86). Also, intracisternal type A particles have been found in guinea pig placentas (120).

In assessing the possible significance of these data, it is important to recall that the placental tissue in which virus-like particles were noted had been taken from "normal" animals showing no trace of neoplastic disease.

Most theories that link embryogenesis and virogenesis explicitly or implicitly infer that type $\mathrm{C}$ virions or their progenitors may act as agents of cellular differentiation. Although support for this concept is still largely inferential, some suggestive observations have been made by Dube et al. (69). These workers studied the induction of endogenous and spleen focus-forming viruses (SFFV) in transformed mouse erythroleukemia cells. Such cells provide an interesting model system as they can be induced to differentiate (i.e., synthesize globin) by dimethylsulfoxide. Dube et al. (69) found that the dimethylsulfoxide-promoted differentiation was accompanied by a 10 - to 100 -fold increase in the release of biologically active Friend virus. A clone of SFFV-transformed cells unable to undergo differentiation did not produce virus. One could argue from this that the enhanced release of Friend virus and the erythroid differentiation of the cell are biochemically coupled events. The ability of Friend SFFV to induce erythropoiesis in the absence of the normal humoral regulator (erythropoietin) has recently been confirmed in vitro by Clarke et al. (48). Also, a 10- to 20-fold increment in the number of intracisternal type A-like particles was noted during the differentiation of "virus-negative" B8 cells. However, it is impossible, on the basis of available evidence, to determine whether such phenomena are fundamental to differentiation or represent trivial side-effects. Several bromodeoxyuridineresistant transformed cell lines did not release type $C$ viruses on exposure to dimethylsulfoxide but did synthesize hemoglobin (203).

A similar situation prevails with avian RNA tumor viruses; Groudine and Weintraub (87) have demonstrated that although DNA comple- mentary to chicken globin mRNA is not detectable in normal uninfected chicken fibroblasts, embryonic globin mRNA sequences accumulate when cells are transformed with Rous sarcoma virus (RSV). RSV appears to selectively activate elements of the host genome.

A finding of considerable significance has been the demonstration that, at least for the avian sarcoma viruses, the maintenance of the transformed state is controlled by one genethe so-called sarc gene-(262). Stehelin et al. (244) have shown that DNA complementary to the sarc gene hybridizes with the DNA of normal chicken cells. However, the $T_{m}$ values for cDNA sarc duplexes and normal cellular DNA indicate a considerable degree of genetic dissimilarity. Such divergences suggest that the RSV sarc gene may have originated in the cell DNA of a different host species or that the neoplastic potential of the virus-acquired gene is the result of substantial mutation in a cellular gene of the homologous host species. The stringent conservation of this locus has suggested to Stehelin et al. (244) that the original sarc gene serves a function in normal cell biochemistry. It will be of considerable interest to determine whether sarc-like sequences are expressed during normal embryogenesis.

Perhaps the most direct evidence for an involvement of viral genes in development has come from the biochemistry of certain proteins that occur in RNA tumor viral membranes Yoshiki et al. (270) have detected such "virusspecific" proteins in the membranes of normal lymphoid tissues from high-leukemic strains of mice. Kurth (147), in a recent review, has summarized evidence which indicates that the viral protein 69/71 occurs in normal fetal tissue. An interesting feature of this report was the suggestion that the expression of the "viral" polypeptide(s) may follow a precise pattern with respect to tissue distribution and the kinetics of appearance/disappearance. Kurth notes that the presence of viral proteins in normal fetal membranes would explain the selective advantage enjoyed by endogenous viral sequences if cell-to-cell surface contacts play a role in directing morphogenetic processes or in maintaining their results. In this context, it is of interest to note that the transformation-specific surface antigen in virally transformed cells is deemed to be a candidate for the product of the sarc gene (262).

\section{RNA TUMOR VIRUSES IN INTERSPECIFIC GENE TRANSFER}

Although the involvement of RNA tumor viruses in embryogenesis must still be considered 
speculative, the transmission of type $C$ virus genes between heterologous species seems well documented. Sequences related to the RNA of an endogenous cat virus (RD-114) have been shown to occur in the cellular DNA of many primates; it has been concluded (22) that viruses originating in primates infected the ancestors of the domestic cat about 3 to 10 million years ago. The transfected genes have become a stable element in the germ line of cats. Some viruses isolated from mice are also related to primate viruses; for example, 5-bromodeoxyuridine treatment of a clone isolated from the feral Asian mouse Mus caroli resulted in the release of a xenotropic virus that was shown to be similar to the type $C$ viruses isolated from the woolly monkey (SSAV) and gibbons (GALV) (154). As sequences homologous to those of SSAV and GALV have not been detected in the cell DNA of normal primates, the inference is that the infectious primate viruses arose by trans-species infection of certain primates with endogenous murine viruses (see also reference 268 ).

Cats appear to have acquired a further class of type $\mathrm{C}$ viruses by infection in the past. Molecular hybridization studies indicate that feline leukemia viruses were transmitted from an ancestor of the rat to ancestors of the domestic cat and the related species Felis sylbestris, $F$. margarita, and $F$. chaus (see reference 254). A further example involving a rodent donor is the domestic pig; cell cultures of the domestic pig and related species such as the European wild boar and the African bush pig contain viral sequences related to murine cell DNA (23). $\mathrm{Hy}$ bridization data suggest that the virus-related sequences in the pig were acquired from members of the family Muridae after the mouse had separated from the rat but before speciation of surviving mice had occurred (254).

As Todaro (254) has emphasized, the RNA tumor viruses are the only group of viruses that have been shown to transfer genes among the germ lines of different species under natural conditions. It is therefore tempting to ascribe to these viruses some positive role in the evolution of higher organisms (below).

\section{RNA TUMOR VIRUSES AND REGULATORY PROCESSES IN HIGHER ORGANISMS}

As noted in the section, Two Types of Molecular Evolution, an increasing weight of evidence sustains the view that the evolution of the higher metazoa depends, not on the development of new proteins, but upon changes in patterns of gene regulation.
All models of metazoan gene regulation implicate repetitive DNA. In this context, two observations are of considerable interest: first, Gillespie and Gallo (82) have shown that about $40 \%$ of the RNA of endogenous (class I) tumor viruses anneals selectively with repetitious cell DNA sequences; second, Gillespie and Gallo (83) have demonstrated that the rate at which RNA tumor viruses evolve is substantially faster than the rate at which structural genes accumulate mutations. This suggests that the rapidly evolving sections of RNA tumor virus genomes are the repeated sequences.

Data presented earlier in this article confirm the concept that adaptive responses in bacteria are achieved primarily through ECE-mediated recombinational processes in which repeated sequences play a key role. I suggest that all metazoan chromosomes contain unstable loci that are preferred sites for the rapid attainment of genetic novelty. In vertebrates, RNA tumor viruses evolve from such regions (see references 82 and 251). Because they involve repeated cell sequences, a prime effect of this programmed genetic flexibility may be corresponding malleability in regulatory processes. On the gross level, this may lead to quite drastic tissue and organ modifications. According to this view endogenous tumor viruses are not so much a result as a cause of the accelerated anatomical evolution observed by Wilson et al. (264).

\section{EPIGENETIC ELEMENTS IN ANIMALS AND IN PLANTS}

Temin (251) has postulated that processes of RNA-directed DNA synthesis have provided a substratum for both embryogenesis and evolution. However, the protovirus hypothesis requires that type $\mathrm{C}$ virions be able to evolve from such processes. By implication, where RNA tumor viruses are absent, one must infer either that the RNA $\rightarrow$ DNA pathway is not utilized in the taxon concerned or that the epigenetic agent does not resemble an oncornavirion.

I have suggested previously in this article and elsewhere (211) that a process of RNA $\rightarrow$ DNA synthesis can occur in metazoan cells and that multicellular organisms could not have evolved without such an activity. I wish to point out here that epigenetic agents in orders outside the vertebrates need not conform to the pattern specified by RNA tumor viruses. This would be especially true of the plant kingdom. Indeed, basic biological principles predict that epigenetic elements in plants would differ fundamentally from their counterparts in higher animals. First, whereas membrane-to-membrane contacts are of prime importance in ani- 
mal embryogenesis, the deposition of lignin and cellulose around plant cells may be expected to minimize the significance of the plasma membrane in processes of plant growth and differentiation. Thus, it is not surprising that most plant viruses lack lipoprotein envelopes. The only budding genus well represented in plants (i.e., the rhabdovirus group) was probably introduced by insects from an animal source, insect or vertebrate. Second, the mode of cell-tocell communication via plasmadesmata in plants has no equivalent in animals. Although there is convincing evidence that viruses may pass from cell to cell via plasmadesmata (141), it seems likely that small, geometrical particles or duplex RNAs would be more readily transmitted than larger enveloped entities. Finally, in many plants, the differentiation between somatic and generative tissue is seasonal. This is perhaps one reason why so many plant cells remain pluripotent (259). The retention of pluripotency into adult life may mean that if endogenous processes of RNA-dependent RNA synthesis (16) exist in plants, they may be rather readily reactivated. This, in turn, would provide an explanation for the predominantly RNA character of plant viral genomes (209), if it can be shown that such viruses or their cellular progenitors serve the epigenetic function imputed to them (see below).

\section{POSSIBLE CANDIDATES FOR EPIGENETIC AGENTS IN PLANTS}

\section{Viroids}

Diener and Takahashi (65) have inferred that the RNA of potato spindle tuber viroid (PSTV) has a DNA equivalent. Semancik and Geelen (232) have found viroid-specific DNA in tissues of plants infected with the agent of citrus exocortis disease (CEV). Semancik and Geelen found no evidence for CEV-specific sequences in uninfected cells. By contrast Diener (personal communication) has detected sequence homology between PSTV RNA, and normal cell DNA.

It seems likely that the DNA of plant cells, like that of animals, consists of interspersed repetitive and unique sequences. Many of the repeated sequences may constitute palindromes (265). The properties of viroids are consistent with the view that such agents arise from palindromic DNA (211); thus, the moderately repeated sequences in eukaryotic DNA are about 200 to 300 bases long in most of the taxa described (45), and viroids are about 250 to 300 bases long (63). Further, the physical properties of viroids (64) are to a large extent those expected of the transcriptional product of an imperfect palindrome.

PSTV has been shown to lack detectable mRNA or tRNA activity (90). If viroids arise by variational genetic events from palindromic DNA, they may be regarded as abnormal cell regulatory RNAs $(209,211)$. The finding of viroid-specific DNA in normal plant cells - if confirmed - would support this concept, although precise roles for such previroid cell RNAs remain speculative.

PSTV and CEV produce identical disease symptoms across a variety of hosts: this might imply that both diseases are caused by the same pathogen. However, Dickson and coworkers (63) have shown that PSTV and CEV differ in primary structure. They are thus specific agents affecting cell chemistry in such a way as to produce similar symptoms.

I suggest then that viroids in plants, like RNA tumor viruses in animals, are (i) of recent evolutionary origin, (ii) derive from cellular sequences whose products are active in growth and morphogenesis, and (iii) adversely affect the regulatory systems of their host(s).

\section{Control Elements}

McClintock (163) has described an entity in maize that has interesting properties suggestive of an epigenetic function. This "control" element can, depending on its chromosomal location, affect diverse genetic markers. It can undergo duplication and transposition within one plant. McClintock (163) has argued that such control elements play specific roles in normal plant ontogeny. This concept has been critically reviewed by Fincham and Sastry (76), who stress the functional similarity of control elements to IS agents.

Clearly, until the molecular nature of control elements is known, speculation as to their origin is meaningless. It is worth noting, however, that an effect similar to that induced by control elements has been reported by Sprague and McKinney $(240,241)$, who noted aberrant Mendelian ratios among the F2 and backcross progeny of plants parentally infected with barley stripe and certain other plant viruses. Rather than postulate that control elements are "tamed" viruses, however, I suggest that certain states of the control elements represent the first steps towards a condition of replicative autonomy that reaches its terminal state in certain plant viruses.

\section{Geometrical Plant Viruses}

Many apparently uninfected plants can be shown to contain geometrical plant viruses 
when their sap is innoculated onto indicator plants. A question of key importance is whether the cellular DNA of such plants contains virus-specific sequences. Reid and Matthews (216) have proposed that green areas in the mosaic caused by turnip yellow mosaic virus (TYMV) contain TYMV in a "lysogenic" state similar to that observed in bacteria. Chalcroft and Matthews (44) have presented evidence that the islands of tissue in the mosaic represent clones of cells that originate from a dividing cell infected by a mutant "substrain" of the TYMV stock. If the original infecting mutant is transmitted to daughter cells (thereby excluding other strains), then the clonal formation of distinctive islands of tissue suggests some stable association between the original infected cell and the mutant viral nucleic acid.

Iodinated probes should make it possible to determine whether plant DNA contains integrated viral sequences.

\section{AN INTEGRATED THEORY OF EVOLUTION}

According to prevailing views, evolution proceeds through selection of genotypes with survival advantages. Among bacteria, the short generation times and large population sizes are thought to provide a sufficiently large spectrum of mutant phenotypes to meet most stress situations. This thesis is supported by virtually the entire weight of laboratory studies in microbial genetics, which show that modulated mutants can be identified in any locus. Among higher cells the sexual mechanism permits hidden variations to be stored as heterozygotes and periodically exposed to the test of selection as homozygotes (95). Novel DNA combinations are generated by meiotic crossovers. The blend of these concepts has produced the orthodox neo-Darwinian view of evolution, which is accepted by virtually all biologists.

Although a minor adaptive role for recombinational processes in bacteria has been conceded since the discovery of $F$ factors, the bulk of ECEs has not been implicated directly in adaptive processes. Only during 1974 and 1975 have a substantial number of papers appeared that specifically relate aspects of evolution to ECE structure and function. In this article, I have attempted to explore, in a systematic way, the concept that evolution may have proceeded largely, rather than peripherally, through ECEs.

As our starting point, I take the facts now emerging concerning the functional organization of chromosomes. I note that genomes con- tain symmetrical sequences as target sites for restriction enzymes, as control sequences (operators, etc.), and as initiation sites for DNA synthesis, etc. Such sequences, which frequently lie outside structural genes, are repeated either inversely (palindromes) or tandemly. The extremely promiscuous IS elements characteristically consist of inverted or tandem DNA repetitions. In my view, these sequences have been tailored by selection to create preferred sites for recombination. To generalize, the modular character of genomes provides for a ready exchange of functional DNA blocks: this may occur within one cell or-wherever effective mechanisms of cell-to-cell gene transfer exist-between cells.

Tandem sequence duplications may be frequent recombinational events. Their frequency can be elevated by mutagens, and, in my view, is sensitive to a variety of environmental pressures. This process may be so easily accomplished by endogenous enzymes in cells that special mechanisms may have been produced to conserve the genetic organization of cells in unstressed conditions. Duplication destabilizes genetic organization because it renders the DNA prone to recombination. Tandem reiterations are known to be unstable in prokaryotes $(225,125)$ and in higher organisms (197). What has not been widely recognized is that duplication tends to create circular mini-DNAs by reciprocal crossover between any regions of repeated homology, i.e., reiterated DNA favors the formation of ECEs (209). Among bacteria, there appear to be a number of modular regions (e.g., prophages) that can readily be excised from the genophore to produce independent replicons. Such is the plasticity of recombinational sites and enzymes that these replicons may frequently be fused to (duplicate) genes flanked by IS elements to generate a huge number of autonomous ECEs carrying virtually any gene in the composite genome of the population, either singly or in combination. This appears to be the way in which $R$ factors and conversion phages have evolved. Among eukaryotes, the requirement that (duplicated) DNA must be excised to create an ECE is not obligatory in many instances. Higher cells appear to contain the enzyme reverse transcriptase, hence eukaryote ECEs may be generated from RNA without DNA deletions.

One of the major advances in evolution must have been the development, possibly in the early or mid-Cambrian period, of effective modes of cell-to-cell gene transfer. The first such adaptations probably merely stabilized polynucleotide exchanges by packaging trans- 
ferred nucleic acid units into protein capsules. A major divergence in evolution appears to have occurred during the pre-Cambrian period. One phyletic line (ancestral prokaryotes) reduced genome size so as to capitalize on the advantages of a rapid rate of reproduction (210). Once selection had reduced genome size to the point where almost all genes were represented by one copy only, a paradox arose since the emergence of any novel function now meant loss of a preexisting vital gene (210). The adaptive answer to this problem has been a widespread extension of host ranges among prokaryote ECEs (plasmids and phages) such that a monoclonal population can draw upon the genetic experience of entire ecosystems in any adaptive response to stress (Fig. 1 and 2). Although some of these processes merely redistribute existing variations among different species, the flexibility of the cell-ECE partnership permits genetic innovations to be created at levels vastly in excess of those attainable by purely entropic or modulated mutation. Although a diverse spectrum of ECEs has been generated among prokaryotes, two "classes" have proved especially successful. The first is the bacteriophage-type particle, the head of which contains DNA while the tail permits effective cell adsorption and cell wall penetration. Almost all contemporary prokaryotes appear to contain genes for the construction of such particles. The second has been the process of direct cell-to-cell transfer via mating. The two may not represent independent lines of evolution. As Campbell (39) and Novick (191) have noted the filamentous DNA phages strongly resemble the conjugative plasmidspecified pili that promote gene transfer.

The second major phyletic line was represented by larger cells that retained substantial elements of repeated DNA. These ancestral eukaryotic organisms almost certainly possessed ECEs and the associated mechanisms of cell-tocell gene transfer. When cells of this type began to associate into "societies," such interconnections quite possibly provided the necessary genetic substratum for metazoan evolution. Whereas selection has among prokaryotes acted to diversify the cell specificity of ECEs, in the cell populations of metazoan organisms selection may have acted to refine and coordinate processes of cell-to-cell nucleic acid transfer so as to permit a specific and integrated programme of embryogenesis. The group of ECEs most intimately involved in the development of highly sophisticated organisms has been those "virions" whose RNA is enveloped in bilayer lipoprotein membranes $(211,251)$. All verte- brate chromosomes contain the information for a diversity of these class I oncornaviruses, and the dependence of ontogenic processes upon such entities is consistent with electron microscope studies $(73,239)$ that show up large numbers of budding particles in embryonic tissues.

The putative ability of genes to be passaged among the cell population of a developing embryo leads almost inevitably to the ability of such genes to pass from one organism to another via ECEs. The adaptive importance of ECEs appears to differ between plants and animals. Plants are sessile and hence the need for rapid, flexible adaptive responses has been more pressing in the plant kingdom (see reference 211).

Although plants, like all higher metazoa, have a sexual mechanism, they are dependent for fertilization upon the same random processes (wind, passive insect transfer) that disseminate viruses. The particular adaptive problems faced by plants are reflected in the character of their associated ECEs: plant viruses have extraordinarily wide host ranges. Tobacco ringspot virus, for example, infects 246 species distributed among 54 families (237). This enables plants to exchange genes among widely separated taxonomic groups and may explain the sporadic occurrence of certain unusual enzyme systems among divergent plant species (Table 7). Further, plant ontogeny is less stringently controlled than animal ontogeny; hence, plant ECEs tend to be simpler in structure than many animal viruses and to contain RNA almost exclusively.

Brooks and Shaw (35) have commented upon the extremely long time lag that intervenes between the emergence of the earliest microfossils (184) and the rich adaptive radiation that began about 800 million years ago and, within a relatively short time span, produced the progenitors of most existing phyla. I suggest that this billion-year-long interval represents the period during which most evolution depended first on entropic and latterly on modulated mutation. ECEs may well have been present during this interval but, in view of the rather limited genetic diversity of the then existing biota, may have been much less effective than their contemporary descendents. Further, the efficiency of ECE-mediated genetic processes is sensitively dependent upon population density; during the earliest phases of biological evolution, the total population size of the biosphere must have been less by very many orders of magnitude than that sustained by the modern earth.

Many of the concepts in this article may have 
to be modified in the light of further data. However, it is now established that ECEs play a fundamental role in processes of natural evolution among bacteria. It seems rather likely that ECEs are implicated in developmental processes among metazoans. If this is true and if ECEs still provide the broad substratum of genetic plasticity through which most adaptive processes work, then it is clear that ECEs must be shifted away from the periphery of evolutionary biology towards its center. It is in the hope that it will provoke discussion and experiment along these lines that I offer this review to the criticism of my colleagues.

\section{ACKNOWLEDGMENTS}

I would like to thank the following colleagues for critical reading of the various drafts of this manuscript: J. Langridge (Commonwealth Scientific and Industrial Research Organization, Canberra, Australia), A. Gibbs (Research School of Biological Sciences, Australian National University, Canberra, Australia), A. Nahmias (Emory University School of Medicine, Atlanta, Ga.), R. Ralph and P. Bergquist (Department of Cell Biology, University of Auckland, Auckland, New Zealand), and B. Howard (Lincoln College, Canterbury, New Zealand).

\section{LITERATURE CITED}

1. Ackermann, H. W. 1974. Bacteriophages - the morphology of bacteriophages, p. 573-578. In A. I. Laskin and H. A. Lechevaller (ed.), Handbook of microbiology, vol. I. CRC Press, Cleveland, Ohio.

2. Ackermann, H. W. 1974. Tailed bacteriophages: listing by morphological groups, p. 579-607. In A. I. Laskin and H. A. Lechevalier (ed.), Handbook of microbiology. CRC Press, Cleveland, Ohio.

3. Ackermann, H. W., and W. A. Smirnoff. 1975. Lysogeny in Bacillus thuringiensis. 3rd Int. Congr. Virol., Abstr. C406, p. 266.

4. Adelberg, E. A., and P. Bergquist. 1972. The stabilisation of episomal integration by genetic inversion: a general hypothesis. Proc. Natl. Acad. Sci. U. S. A. 69:2061-2065.

5. Ahmad, A., W. K. Holloman, and R. Holliday. 1975. Nuclease that preferentially inactivates DNA containing mismatched bases. Nature (London) 258:54-56.

6. Alff-Steinberger, C. 1969 . The genetic code and error transmission. Proc. Natl. Acad. Sci. U. S. A. 64:584-591.

7. Allet, B., P. G. N. Jeppesen, K. J. Katagiri, and H. Delius. 1973. Mapping the DNA fragments produced by cleavage of $\lambda$ DNA with endonuclease. Nature (London) New Biol. 241:120-123.

8. Ames, B. N., P. E. Hartman, and F. Jacob. 1963. Chromosomal alterations affecting the regulation of histidine biosynthesis enzymes in Salmonella. J. Mol. Biol. 7:23-42.

9. Anderson, E. S. 1966. Possible importance of transfer factors in bacterial evolution. Na- ture (London) 209:637-638.

10. Anderson, E. S. 1968. The ecology of transferable drug resistance in the enterobacteria. Annu. Rev. Microbiol. 22:131-180.

11. Anderson, N. G. 1970. The evolutionary significance of virus infection. Nature (London) 227:1346-7.

12. Aposhian, H. V., P. K. Qasba, D. B. Telton, A. Pletsch, and V. S. Sethi. 1973. The polyoma pseudovirion - its properties, production and use in transferring DNA to mouse and human cells. In R. F. Beers and R. C. Tilgham (ed.), Cellular modification and genetic transformation by exogenous nucleic acids. The John Hopkins University Press, Baltimore.

13. Arber, W. 1974. DNA modification and restriction. Progr. Nucleic Acid Res. Mol. Biol. 14:1-37.

14. Arber, W., and D. Wauters-Willems. 1970. Host specificity of DNA produced by Escherichia coli. XII. The two restriction and modification systems of strain $15 \mathrm{~T}^{-}$. Mol. Gen. Genet. 108:203-217.

15. Artzt, K., and D. Bennet. 1975. Analogies between embryonic $(\mathrm{T} / \mathrm{t})$ antigens and adult major histocompatibility (H-2) antigens. Nature (London) 256:545-547.

16. Astier-Manifacier, S., and P. Cornuet. 1971. RNA-dependent RNA polymerase in chinese cabbage. Biochim. Biophys. Acta 232:484493.

17. Ball, L. A. 1972 . Implications of secondary structure in messenger RNA. J. Theor. Biol. 36:313-320.

18. Barksdale, L., and S. B. Arden. 1974. Persisting bacteriophage infections, lysogeny and phage conversions. Annu. Rev. Microbiol. 28:265-300.

19. Bate-Smith, E. C., and T. Swain. 1966. The asperulosides and the aucubins, p. 159-174. In T. Swain (ed.), Comparative phytochemistry. Academic Press Inc., New York.

20. Benveniste, R., and J. Davies. 1973. Mechanisms of antibiotic resistance in bacteria. Annu. Rev. Biochem. 42:471-506.

21. Benveniste, R., and J. Davies. 1973. Aminoglycoside antibiotic inactivating enzymes in Actinomycetes similar to those present in clinical isolates of antibiotic resistant bacteria. Proc. Natl. Acad. Sci. U. S. A. 70:2276-2280.

22. Benveniste, R., and G. J. Todaro. 1974. Evolution of C-type viral genes: inheritance of exogenously acquired viral genes. Nature (London) 252:456-459.

23. Benveniste, R., and G. J. Todaro. 1975. Evolution of $\mathbf{C}$ viral genes: preservation of ancestral murine type $\mathrm{C}$ viral sequences in pig cellular DNA. Proc. Natl. Acad. Sci. U. S. A. 72:4090-4095.

24. Berg, D. E., J. Davies, B. Allet, and J. D. Rochaix. 1975. Transposition of $R$ factor genes to bacteriophage $\lambda$. Proc. Natl. Acad. Sci. U. S. A. 72:3628-3632.

25. Betz, J. L., P. R. Brown, M. J. Symth, and P. 
H. Clarke. 1974. Evolution in action. Nature (London) 247:261-264.

26. Blundell, T. L., and S. P. Wood. 1975. Is the evolution of insulin Darwinian or due to selectively neutral mutation? Nature (London) 257:197-203.

27. Bonner, J., and J.-R. Wu. 1973. A proposal for the structure of the Drosophila genome. Proc. Natl. Acad. Sci. U. S. A. 70:535-537.

28. Boram, W., and J. Abelson. 1973. Bacteriophage $\mathrm{Mu}$ integration: on the orientation of the prophage. Virology 54:102-108.

29. Bostock, C. 1971. Repetitious DNA. In D. M. Prescott, L. Goldstein, and E. McConkey (ed.), Advances in cell biology, vol. 2. Appleton-Century-Crofts, New York.

30. Botstein, D., and I. Herskowitz. 1974. Properties of hybrids between Salmonella phage P22 and coliphage $\lambda$. Nature (London) 251:584-589.

31. Bott, K., and B. Strauss. 1965. The carrier state of Bacillus subtilis infected with the transducing bacteriophage SP10. Virology 25:212-225.

32. Bray, D., and P. W. Robbins. 1967. Mechanism of $\mathrm{e}^{15}$ conversion studied with bacteriophage mutants. J. Mol. Biol. 30:457-475.

33. Britten, R. J., and E. H. Davidson. 1969. Gene regulation for higher cells: a theory. Science 165:349-357.

34. Brockman, W. W., T. N. H. Lee, and D. Nathans. 1973. The evolution of new species of viral DNA during serial passage of SV-40 at high multiplicity. Virology 54:384-397.

35. Brooks, J., and G. Shaw. 1973. Origin and development of living systems. Academic Press Inc., New York.

36. Brutlag, D., and A. Kornberg. 1972. Enzymatic synthesis of DNA. XXXVI. A proofreading function for the $3^{\prime} \rightarrow 5^{\prime}$ exonuclease activity in DNA polymerases. J. Biol. Chem. 247:241-248.

37. Bukhari, A. I., and M. Metlay. 1973. Genetic mapping of prophage Mu. Virology 54:109 116.

38. Bukhari, A. I., and D. Zipser. 1972. Random insertion of Mu-1 DNA within a single gene. Nature (London) 236:240-243.

39. Campbell, A. M. 1969. Episomes. Harper \& Rowe, Publishers, New York.

40. Campbell, A. M. 1973. Episomes in evolution, p. 534-561. In H. H. Smith (ed.), Evolution of genetic systems. Gordon and Breach, New York.

41. Chakrabarty, A. M. 1972 . Genetic basis of the biodegradation of salicylate in Pseudomonas. J. Bacteriol. 112:815-823.

42. Chakrabarty, A. M., G. Chou, and I. C. Gunsalus. 1973. Genetic regulation of octane dissimilation plasmid in Pseudomonas. Proc. Natl. Acad. Sci. U. S. A. 70:1137-1140.

43. Chakravorty, M. 1970. Induction and repression of $\mathrm{L}$-arabinose isomerase in bacteriophage infected Salmonella typhimurium. J. Virol. 5:541-547.
44. Chalcroft, J. P., and R. E. F. Matthews. 1967. Role of virus strains and leaf ontogeny in the production of mosaic patterns by turnip yellow mosaic virus. Virology 33:659-673.

45. Chamberlin, M. E., R. J. Britten, and E. H. Davidson. 1975. Sequence organisation in Xenopus DNA studied by the electron microscope. J. Mol. Biol. 96:317-333.

46. Chou, G. I., D. Katz, and I. C. Gunsalus. 1974. Fusion and compatibility of camphor and octane plasmids in Pseudomonas. Proc. Natl. Acad. Sci. U. S. A. 71:2675-2678.

47. Christiansen, C., G. Christiansen, A. L. Bak, and A. Stenderup. 1973. Extrachromosomal deoxyribonucleic acid in different enterobacteria. J. Bacteriol. 114:367-377.

48. Clarke, B. J., A. A. Axelrad, M. M. Shreeve, and D. L. McLeod. 1975. Erythroid colony induction without erythropoietin by Friend leukemia virus in vitro. Proc. Natl. Acad. Sci. U. S. A. 72:3556-3560.

49. Coetzee, J. N., and A. O. Hawtrey. 1962. A change in phenotype associated with the bacteriophage carrier state in a strain of Proteus mirabilis. Nature (London) 194:1196-1197.

50. Cohen, S. N., and A. C. Y. Chang. 1973. Recircularisation and autonomous replication of a sheared R-factor DNA segment in Escherichia coli transformants. Proc. Natl. Acad. Sci. U. S. A. 70:1293-1297.

51. Colasito, D. J., and M. H. Rogoff. 1969. Characterisation of temperate bacteriophages of Bacillus thuringiensis. J. Gen. Virol. 5:275281.

52. Cox, E. C., and C. Yanofsky. 1967. Altered base ratios in the DNA of an $E$. coli mutator strain. Proc. Natl. Acad. Sci. U. S. A. 58:1895-1902.

53. Cozzarelli, N. R., R. B. Kelly, and A. Kornberg. 1968. A minute, circular DNA from $E$. coli. Proc. Natl. Acad. Sci. U. S. A. 60:992999.

54. Crick, F. H. C. 1968. Origin of the genetic code. J. Mol. Biol. 38:367-379.

55. Crick, F. H. C. 1971 . General model for the chromosomes of higher organisms. Nature (London) 234:25-27.

56. Crill, P., D. J. Hagedorn, and E. W. Hanson. 1970. Alfalfa mosaic, the disease and its incitant. W. D. Agric. Exp. Stn. Res. Bull. no. 280.

57. Datta, N., R. W. Hedges, E. J. Shaw, R. B. Sykes, and M. H. Richmond. 1971. Properties of an $\mathbf{R}$ factor from Pseudomonas aeruginosa. J. Bacteriol. 108:1244-1249.

58. Datta, N., and R. W. Hedges. 1972. Host ranges of $\mathbf{R}$ factors. J. Gen. Microbiol. 70: 453-460.

59. Davidson, N., R. C. Deonier, S. Hu, and E. Ohtsubo. 1975. Electron microscope heteroduplex studies of sequence relations among plasmids of Escherichia coli. X. DNA sequence organisation of F and F-primes and the sequences involved in $\mathrm{Hfr}$ formation. $\mathrm{Mi}$ crobiology 1:56-65. 
60. Davoli, D., and G. C. Fareed. 1974. Amplification of a circular segment of SV-40 DNA. Nature (London) 251:153-155.

61. Dewees, A. A. 1975. Genetic modification of recombination rate in Tribolium castaneum. Genetics 81:537-552.

62. Dickerson, R. E. 1973. Molecular evolution. In H. O. Wilson, T. Eisner, W. R. Briggs, R. E. Dickerson, R. L. Metzenberg, R. D. O'Brien, M. Susman, and W. E. Boggs (ed.), Life on earth. Sinauer Associates Inc., Stanford, Conn.

63. Dickson, E., W. Prensky, and H. D. Robertson. 1975. Comparative studies of two viroids: analysis of potato spindle tuber and citrus exocortis by RNA fingerprinting and polyacrylamide gel electrophoresis. Virology 68:309-316.

64. Diener, T. O. 1972. Potato spindle tuber viroid. VIII. Correlation of infectivity with a uvabsorbing component and thermal denaturation properties of the RNA. Virology 50:606609.

65. Diener, T. O., and T. Takahashi. 1975. Viroid replication. 3rd Int. Congr. Virol., Abstr. W15, p. 82.

66. Doermann, A. H. 1973. T4 and the rolling circle model of replication. Annu. Rev. Genet. 7:325-342.

67. Donini, P. 1972. Turnover of ribosomal RNA during the stringent response in Escherichia coli. J. Mol. Biol. 72:553-569.

68. Dove, W. 1971. In A. D. Heshey (ed.), The bacteriophage lambda, p. 3-45. Cold Spring Harbor Laboratory, Cold Spring Harbor, N.Y.

69. Dube, S. K., I. B. Pragnell, N. Fluge, G. Gaedicke, G. Steinheider, and W. Ostertag. 1975. Induction of endogenous and of spleen focus-forming viruses during dimethylsulfoxide-induced differentiation of mouse erythroleukemia cells transformed by spleen focus-forming virus. Proc. Natl. Acad. Sci. U. S. A. 72:1863-1867.

70. Dunn, N. W., and I. C. Gunsalus. 1973. Transmissable plasmid coding early enzymes of napthalene oxidation in Pseudomonas putida. J. Bacteriol. 114:974-979.

71. Emmons, S. W., V. MacCosham, and R. L. Baldwin. 1975. Tandem genetic duplication in phage lambda. III. The frequency of duplication mutants in two derivatives of phage lambda is independent of known recombination systems. J. Mol. Biol. 91:133-146.

72. Falkow, S., E. M. Johnson, and L. S. Baron. 1967. Bacterial conjugation and extrachromosomal elements. Annu. Rev. Genet. 1:87116.

73. Feldman, D. 1975. An electron microscope study of virus particles in Rhesus monkey placenta. Proc. Natl. Acad. Sci. U. S. A. 72:118-121.

74. Fiandt, M., W. Szybalski, and M. H. Malamy. 1972. Polar mutations in LAC, GAL, and phage $\lambda$ consist of a few IS-DNA sequences inserted with either orientation. Mol. Gen.
Genet. 119:223-231.

75. Fiers, W., R. Contreras, F. Duerinck, G. Haegeman, D. Iserentant, J. Merregaert, W. Min Jou, F. Molemans, A. Raeymaekers, A. Van den Berghe, G. Volckaert, and M. Ysebaert. 1976. Complete nucleotide sequence of bacteriophage MS2 RNA: primary and secondary structure of the replicase gene. $\mathrm{Na}$ ture (London) 260:500-507.

76. Fincham, J. R. S., and G. R. K. Sastry. 1974 Controlling elements in maize. Annu. Rev. Genet. 8:15-50.

77. Franklin, N. C. 1971. Illegitimate recombination, p. 175-194. In A. D. Hershey (ed.), The bacteriophage lambda. Cold Spring Harbor Laboratory, Cold Spring Harbor, N.Y.

78. Garro, A. J., and L. Ming-Fan. 1974. Relationship between lysogeny, spontaneous induction and transformation efficiencies in Bacillus subtilis. J. Bacteriol. 120:1256-1259.

79. Gatlin, L. 1972. Information theory and the living system. Columbia University Press, New York.

80. Gilbert, W., and A. Maxam. 1973. The nucleotide sequence of the LAC operator. Proc. Natl. Acad. Sci. U. S. A. 70:3581-3585.

81. Gill, D. M., T. Uchida, and R. A. Singer. 1972 Expression of diptheria toxin genes carried by integrated and non-integrated phage beta. Virology 50:664-668.

82. Gillespie, D., and R. C. Gallo. 1975. RNA processing and RNA tumor virus origin and evolution. Science 188:802-811.

83. Gillespie, D., and R. C. Gallo. 1975. Hybridisation of tumor virus RNA to DNA from cells. 3rd Int. Congr. Virol., Abstr. W41, p. 137.

84. Goldberg, I. D., and T. Bryan. 1968. Productive infection of Bacillus subtilis 168 with bacteriophage SP-10. J. Virol. 2:805-812.

85. Goodman, M., G. W. Moore, and G. Matsuda. 1975. Darwinian evolution in the geneaology of haemoglobin. Nature (London) 253:603608.

86. Gross, L., G. Schidlovsky, D. Feldman, Y. Dreyfuss, and L. A. Moore. 1975. C-type virus particles in placenta of normal healthy Sprague-Dawley rats. Proc. Natl. Acad. Sci. U. S. A. 72:3240-3244.

87. Groudine, M., and H. Weintraub. 1975. Rous sarcoma virus activates embryonic globin genes in chicken fibroblasts. Proc. Natl. Acad. Sci. U. S. A. 72:4464-4468.

88. Guerineau, M., P. P. Slonimski, and P. R. Avner. 1974. Yeast episome: oligomycin resistance associated with a small covalently closed non-mitochondrial circular DNA. Biochem. Biophys. Res. Commun. 61:462-469.

89. Gyles, C., M. So, and S. Falkow. 1974. The enterotoxin plasmids of Escherichia coli. J. Infect. Dis. 130:40-49.

90. Hall, T. C., R. K. Wepprich, J. W. Davies, L. G. Weathers, and J. S. Semanick. 1974. Functional distinctions between the RNA from citrus exocortis viroid and plant viruses: cell-free translation and aminoacyla- 
tion reactions. Virology 61:486-492.

91. Hansche, P. E. 1975. Gene duplication as a mechanism of genetic adaptation in Saccharomyces cerevisiae. Genetics 79:661-674.

92. Harada, K., M. Kameda, M. Suzuki, R. Egawa, and S. Mitsuhashi. 1961. Studies on the drug resistance of enteric bacteria. 10. Relation between transmissable drug resistance (R) factor and fertility (F) factor in $E$. coli strain K12. Jpn. J. Exp. Med. 31:291299.

93. Harbourne, J. B. 1966. The evolution of flavonoid pigments in plants, p. 271-297. In $\mathrm{T}$. Swain (ed.), Comparative phytochemistry. Academic Press Inc., New York.

94. Hattman, S., E. Gold, and A. Plotnik. 1972 Methylation of cytosine residues in DNA controlled by a drug resistance factor. Proc. Natl. Acad. Sci. U. S. A. 69:187-190.

95. Hayes, W. 1968. The genetics of bacteria and their viruses. Blackwell, Oxford.

96. Hayward, W. S., and H. Hanafusa. 1973. Detection of avian tumor virus RNA in uninfected chicken embryo cells. J. Virol. 11:157167.

97. Hedges, R. W., N. Datta, P. Kontomichalou, and J. T. Smith. 1974. Molecular specificities of $\mathbf{R}$ factor-determined beta-lactamases: correlation with plasmid compatibility. J. Bacteriol. 117:56-62.

98. Hedges, R. W., and A. E. Jacob. 1974. Transportation of ampicillin resistance from $\mathrm{RP}^{4}$ to other replicons. Mol. Gen. Genet. 132:31-40.

99. Hedges, R. W., A. E. Jacob, N. Datta, and J. N. Coetzee. 1975. Properties of plasmids produced by recombination between $R$ factors of groups $I$ and $F_{\text {II. }}$. Mol. Gen. Genet. 140:289302.

100. Hedgpeth, J., H. M. Goodman, and H. W. Boyer. 1972. DNA nucleotide sequence restricted by the R1 endonuclease. Proc. Natl. Acad. Sci. U. S. A. 69:3448-3452.

101. Heffron, F., C. Rubens, and S. Falkow. 1975. Translocation of a plasmid DNA sequence which mediates ampicillin resistance: molecular nature and specificity of insertion. Proc. Natl. Acad. Sci. U. S. A. 72:3623-3627.

102. Heffron, F., R. Sublett, R. W. Hedges, A. Jacob, and S. Falkow. 1975. Origin of the TEM beta-lactamase gene found on plasmids. J. Bacteriol. 122:250-256.

103. Hegeman, G. C., and S.L. Rosenberg. 1970. The evolution of bacterial enzyme systems. Annu. Rev. Microbiol. 24:429-462.

104. Henneberry, R. C., and B. C. Calton. 1973. Characterization of the polydisperse closed circular DNA of molecules of Bacillus megaterium. J. Bacteriol. 114:625-631.

105. Hershey, A. D. 1971. The bacteriophage lambda. Cold Spring Harbor Laboratory, Cold Spring Harbor, N.Y.

106. Hoess, R. H., and R. K. Herman. 1975. Isolation and characterization of mutator strains of Escherichia coli. J. Bacteriol. 122:474-484.

107. Holloway, B. W., and G. N. Cooper. 1962. Ly- sogenic conversion in Pseudomonas aeruginosa. J. Bacteriol. 84:1321-1324.

108. Holloway, B. W., and V. Krishnapillai. 1975. Bacteriophages and bacteriocins, p. 99-132. In P. Clarke and M. Richmond (ed.), Genetics and biochemistry of Pseudomonas. John Wiley \& Sons, Inc., New York.

109. Hopfield, J. J. 1974. Kinetic proof-reading. a new mechanism for reducing errors in biosynthetic processes requiring high specificity. Proc. Natl. Acad. Sci. U. S. A. 71:41354139.

110. Hotchkiss, R. D. 1974. Models of genetic recombination. Annu. Rev. Microbiol. 28:445468.

111. Hourcade, D., D. Dressler, and J. Wolfson. 1973. The amplification of ribosomal RNA genes involves a rolling circle intermediate. Proc. Natl. Acad. Sci. U. S. A. 70:2926-2930.

112. Howe, M. 1973. Prophage deletion mapping of bacteriophage Mu-1. Virology 54:93-101.

113. Howe, M., and E. G. Bade. 1975. Molecular biology of bacteriophage Mu. Science 190:624-632.

114. Hu, S., E. Ohtsubo, and N. Davidson. 1975. Electron microscope heteroduplex studies of sequence relations among plasmids of $E s c h e-$ richia coli: structure of F13 and related Fprimes. J. Bacteriol. 122:749-763.

115. Hu, S., E. Ohtsubo, N. Davidson, and H. Saedler. 1975. Electron microscope heteroduplex studies of sequence relationships among bacterial plasmids. XII. Identification and mapping of the insertion sequences IS1 and IS2 in $F$ and $R$ plasmids. J. Bacteriol. 122:764-775.

116. Hu, S., K. Ptashne, S. N. Cohen, and N. Davidson. 1975. $\alpha \beta$ sequence of $F$ is IS3. J. Bacteriol. 123:687-692.

117. Huang, W. M., and J. Marmur. 1970. Characterization of inducible bacteriophages in $\mathrm{Ba}$ cillus licheniformis. J. Virol. 5:237-246.

118. Huebner, R. J., G. J. Kelloff, P. S. Sarma, W. T. Lane, H. C. Turner, R. V. Gilden, S. Oroszlan, H. Meier, D. Myers, and R. L. Peters. 1970. Group specific antigen expression during embryogenesis of the genome of the C-type RNA tumor viruses: implications for ontogenesis and oncogenesis. Proc. Natl. Acad. Sci. U. S. A. 67:366-376.

119. Huebner, R. J., and G. Todaro. 1969. The oncogene hypothesis. Proc. Natl. Acad. Sci. U. S. A. 64:1087-1091.

120. Hsiung, G. D., C. K. Y. Fong, and C. H. Evans. 1974. Prevalence of endogenous oncornavirus in guinea pigs. Intervirology 3:319331.

121. Hsu, M., and N. Davidson. 1974. Electron microscope heteroduplex study of the heterogeneity of Mu phage and prophage DNA. Virology 58:229-239.

122. Ikawa, Y., J. Ross, and P. Leder. 1974. An association between globin messenger RNA and 60S RNA derived from Friend leukemia virus. Proc. Natl. Acad. Sci. U. S. A 71:1154-1158 
123. Inoue, M., and S. Mitsuhashi. 1975. A bacteriophage SI derivative that transduces tetracycline resistance to Staphylococcus aureus. Virology 68:544-546.

124. Ioannou, P. 1973. General model for the replication of double-stranded DNA molecules. Nature (London) New Biol. 244:257-260.

125. Jackson, E. N., and C. Yanofsky. 1973. Duplication-translocations of tryptophan operon genes in $E$. coli. J. Bacteriol. 116:33-40.

126. Jacob, A. E., and N. J. Grinter. 1975. Plasmid RP4 as a vector replicon in genetic engineering. Nature (London) 255:504-505.

127. Jacob, F. 1955. Transduction of lysogeny in Escherichia coli. Virology 1:207-220.

128. Jacob, F., P. Schaeffer, and E. L. Wollman. 1960. Episomic elements in bacteria, p. 6791. In $W$. Hayes and $R$. Clowes (ed.), Microbial genetics, 10th Symp. Soc. Gen. Microbiol. Cambridge University Press, Cambridge.

129. Jacob, F., A. Ullman, and J. Monod. 1965. Deletions fusionant l'operon lactose et un operon purine chez $E$. coli. J. Mol. Biol. 13:704719.

130. Jones, D., and P. H. A. Sneath. 1970. Genetic transfer and bacterial taxonomy. Bacteriol. Rev. 34:40-81.

130a. Johnson, E. M., J. A. Wohlhieter, B. P. Placek, R. B. Sleet, and L. S. Baron. 1976. Plasmid-determined ability of Salmonella tennessee strain to ferment lactose and sucrose. J. Bacteriol. 125:385-386.

131. Jones, L. M., C. R. McDuff, and J. B. Wilson. 1962. Phenotypic alterations in the colonial morphology of Brucella abortus due to a bacteriophage carrier state. J. Bacteriol. 83:860866.

132. Kaiser, D., and M. Dworkin. 1975. Gene transfer to a myobacterium by $E$. coli phage P1. Science 187:653-654.

133. Kalter, S. S., R. J. Helmke, R.L. Heberling, M. Pangiel, A. K. Fowler, J. E. Strickland, and A. Hellman. 1973. C-type particles in normal human placentas. J. Natl. Cancer Inst. 50:1081-1084.

134. Kalter, S. S., R. J. Helmke, M. Pangiel, R. L. Heberling, P. J. Felsburg, and L. R. Axelrod. 1973. Observations of apparant C-type particles in Baboon (Papio cynocephalus) placentas. Science 179:1332-1333.

135. Kerszman, G., S. W. Glover, and J. Aronovitch. 1967. The restriction of bacteriophage $\lambda$ in $E$. coli strain W. J. Gen. Virol. 1:333-347.

136. Khoury, G., G. C. Fareed, K. Berry, M. A. Martin, T. N. H. Lee, and D. Nathans. 1974. Characterisation of a rearrangement in viral DNA: mapping of the circular simian virus 40-like DNA containing a triplication of a specific one third of the viral genome. J. Mol. Biol. 87:289-301.

137. Kimura, M. 1969. The rate of molecular evolution considered from the stand point of population genetics. Proc. Natl. Acad Sci. U. S. A. 63:1181-1188.

138. Kimura, M., and T. Ohta. 1973. Mutation and evolution at the molecular level. Genetics ${ }^{\circ}$ 73(Suppl.):19-40.

139. King, M. C., and T. H. Jukes. 1969. Non-Darwinian evolution. Science 164:788-798.

140. King, M. C., and A. C. Wilson. 1975. Evolution at two levels in humans and chimpanzees. Science 188:107-116.

141. Kitajima, E. W., and J. A. Lauritis. 1969. Plant virions in plasmadesmata. Virology 37:681-685.

142. Kjaer, A. 1966. The distribution of sulphur compounds, p. 187-194. In T. Swain (ed.), Comparative phytochemistry. Academic Press Inc., New York.

143. Kleckner, N., R. K. Chan, B. K. Tye, and D. Botstein. 1975. Mutagenesis by insertion of a drug-resistance element carrying an inverted repetition. J. Mol. Biol. 97:561-575.

144. Koch, A. L., and C. Miller. 1965. A mechanism for keeping mutations in check. J. Theor. Biol. 8:71-80.

145. Kolata, G. B. 1975. Evolution of DNA: changes in gene regulation. Science 189:446-447.

146. Kramer, F. R., D. R. Mills, P. E. Cole, T. Nishihara, and S. Spiegelman. 1974. Evolution in vitro: sequence and phenotype of a mutant RNA resistant to ethidium bromide. J. Mol. Biol. 89:719-736.

147. Kurth, R. 1975. Tumour virus proteins and the cell surface. Nature (London) 256:613-614.

148. Lanks, K. W., and F. S. Kitchin. 1970. Conservative mutations in homologous proteins. Nature (London) 226:753-754.

149. Lanni, Y. T. 1968. First-step transfer deoxyribonucleic acid of bacteriophage T5. Bacteriol. Rev. 32:227-242.

150. Lavi, S., and E. Winocour. 1972. Acquisition of sequences homologous to host deoxyribonucleic acid by closed circular simian virus $\mathbf{4 0}$ deoxyribonucleic acid. J. Virol. 9:309-316.

151. Lederberg, J. 1952. Cell genetics and hereditary symbiosis. Physiol. Rev. 32:403-430.

152. Lee, H. J., E. Ohtsubo, R. C. Deonier, and N. Davidson. 1974. Electron microscope heteroduplex studies of sequence relations among plasmids of $E$. coli. V. ilv $^{+}$deletion mutants of F14. J. Mol. Biol. 89:585-597.

153. Li, K., L. Barksdale, and L. Garmise. 1961. Phenotypic alterations associated with the bacteriophage carrier state of Shigella $d y$ senteriae. J. Gen. Microbiol. 24:355-367.

154. Lieber, M. M., C. J. Sherr, G. J. Todaro, R. E. Benveniste, R. Callahan, and H. G. Coon. 1975. Isolation from the Asian mouse Mus caroli of an endogenous type $\mathrm{C}$ virus related to infectious primate type $\mathrm{C}$ viruses. Proc. Natl. Acad. Sci. U. S. A. 72:2315-2319.

155. Lindahl, T. 1974. An N-glycosidase from Escherichia coli that releases free uracil from DNA containing deaminated cytosine residues. Proc. Natl. Acad. Sci. U. S. A. 71:36493653.

156. Lindahl, T. 1976. New class of enzymes acting on damaged DNA. Nature (London) 259:6466 .

157. Lovett, P. S. 1972. PBP1: a flagella specific 
bacteriophage mediating transduction in $B a$ cillus pumilus. Virology 47:743-752.

158. Lovett, P. S. 1973. Plasmid in Bacillus pumilus and the enhanced sorulation of plasmid-negative variants. J. Bacteriol. 120:488-494.

159. Lovett, P. S., and M. G. Bramucci. 1975. Plasmid DNA in Bacillus' subtilis and Bacillus pumilus. J. Bacteriol. 124:484-490.

160. Lovett, P. S., and B. D. Burdick. 1973. Cryptic plasmid in Bacillus pumilus ATCC 7065. Biochem. Biophys. Res. Commun. 54:365-370.

161. Low, K. B. 1972. Escherichia coli K-12 F-prime factors, old and new. Bacteriol. Rev. 36:587607.

162. Luria, S. E., D. K. Fraser, J. N. Adams, and J. W. Burrous. 1958. Lysogenization, transduction and genetic recombination in bacteria. Cold Spring Harbor Symp. Quant. Biol. 23:71-82.

163. McClintock, B. 1967. Genetic systems regulating gene expression during development. Develop. Biol. 1(Suppl.):84-112.

164. McCloy, E. W. 1951. Studies on a lysogenic $B a$ cillus strain. (1). A bacteriophage specific for Bacillus anthracis. J. Hygiene 49:114-125.

165. MacPhee, D. G. 1974. DNA polymerase activity determined by the ultraviolet protecting plasmid, R-Utrecht. Nature (London) 251: 432-434.

166. Majumdar, C., M. Dewey, and F. R. Frankel. 1972. Bacteriophage-directed association of DNA polymerase 1 with host membranes: a dispensable function. Virology 49:134-144.

167. Mäkäla, P. H. 1966. Genetic determination of the $\mathbf{O}$ antigens of Salmonella group B. J. Bacteriol. 91:1115-1125.

168. Maniatis, T., M. Ptashne, B. G. Barrell, and J. Donelson. 1974. Sequence of a repressorbinding site in the DNA of bacteriophage $\lambda$. Nature (London) 250:394-397.

169. Martuscelli, J., A. L. Taylor, D. J. Cummings, V. A. Chapman, S. S. DeLong, and L. Canedo. 1971. Electron microscopic evidence for the linear insertion of bacteriophage Mu-1 in lysogenic bacteria. J. Virol. 8:551-563.

170. Marvin, D. A., and B. Hohn. 1969. Filamentous bacterial viruses. Bacteriol. Rev. 33:172-209.

171. Matsuda, M., and L. Barksdale. 1967. System for the investigation of the bacteriophagedirected synthesis of diptheria toxin. J. Bacteriol. 93:722-730.

172. Matsuyama, T., and H. Uetake. 1972. Chromosomal locations of Salmonella conversion phages: mapping of prophages $\mathrm{g}_{341}, \mathrm{e}^{15}$ and $\mathrm{e}^{34}$ in Salmonella anatum. Virology 49:359-367.

173. Mertz, J. E., and R. W. Davis. 1972. Cleavage of DNA by $R 1$ restriction endonuclease generates cohesive ends. Proc. Natl. Acad. Sci. U. S. A. 69:3370-3374.

174. Meselson, M., and R. Yuan. 1968. DNA restriction enzyme from $E$. coli Nature (London) 217:1110-1114.

175. Meselson, M., R. Yuan, and J. Heywood. 1972. Restriction and modification of DNA. Annu. Rev. Biochem. 41:447-466.
176. Meynell, E., G. G. Meynell, and N. Datta. 1968. Phylogenetic relationships of drug-resistant factors and other transmissable bacterial plasmids. Bacteriol. Rev. 32:55-84.

177. Mills, D. R., F. R. Kramer, and S. Spiegelman. 1973. Complete nucleotide sequence of a replicating RNA molecule. Science 180:916-927.

178. Min Jou W., G. Haegeman, M. Ysebaert, and W. Fiers. 1972. Nucleotide sequence of the gene coding for bacteriophage MS2 coat protein. Nature (London) 237:82-88

179. Monahan, J. J., and R. H. Hall. 1974. Chromatin and gene regulation in eukaryotic cells at the transcriptional level. CRC Crit. Rev. Biochem. 2:67-112.

180. Monod, J. 1970. Chance and necessity. Collins, London.

181. Morrow, J. F., and P. Berg. 1972. Cleavage of simian virus to DNA at a unique site by a bacterial restriction enzyme. Proc. Natl. Acad. Sci. U. S. A. 69:3365-3369.

182. Morrow, J. F., S. N. Cohen, C. Y. Change, H. W. Boyer, H. M. Goodman, and R. B. Helling. 1974. Replication and transcription of eukaryotic DNA in Escherichia coli. Proc. Natl. Acad. Sci. U. S. A. 71:1743-1747.

183. Mourant, A. E. 1971. Transduction and skeletal evolution. Nature (London) 231:466-467.

184. Muir, M. D., and D. O. Hall. 1974. Diverse microfossils in Precambrian Onverwacht group rocks of South Africa. Nature (London) 252:376-377.

185. Mukherjee, B., and P. M. Mobry. 1975. Variations in hybridisation of RNA from different mouse tissues and embryos to endogenous Ctype virus DNA transcripts. J. Gen. Virol. 28:129-135.

186. Murray, N. E., and K. Murray. 1974. Manipulation of restriction targets in phage $\lambda$ to form receptor chromosomes for DNA fragments. Nature (London) 251:476-481.

187. Muzyczka, N., R. L. Poland, and M. J. Bessman. 1972. Studies on the biochemical basis of spontaneous mutation. I. A comparison of the DNA polymerases of mutator, antimutator and wild-type strains of bacteriophage T4. J. Biol. Chem. 247:7116-7122.

188. Nomura, M. 1970. Bacterial ribosome. Bacteriol. Rev. 34:228-277.

189. Novick, A., and L. Szilard. 1951. Virus strains of identical phenotype but different genotype. Science 113:34-35.

190. Novick, R. P. 1966. Extrachromosomal inheritance of antibiotic resistance in Staphylococcus aureus. Postepy Mikrobiol. 5:345.

191. Novick, R. P. 1969. Extrachromosomal inheritance in bacteria. Bacteriol. Rev. 33:210-263.

192. Novick, R. P. 1974. Bacterial plasmids, p. 537586. In A. L. Laskin and H. A. Lechevalier (ed.), Handbook of microbiology, vol. IV. CRC Press, Cleveland, Ohio.

193. Novick, R. P., R. C. Clowes, S. N. Cohen, R. Curtiss, N. Datta, and S. Falkow. 1976. Uniform nomenclature for bacterial plasmids: a proposal. Bacteriol. Rev. 40:168-189.

194. Novick, R. P., and S. I. Morse. 1967. In vivo 
transmission of drug resistance factors between strains of Staphylococcus aureus. J. Exp. Med. 125:45-59.

195. Novick, R. P., and M. H. Richmond. 1965. Nature and interaction of the genetic elements governing penicillinase synthesis in Staphylococcus aureus. J. Bacteriol. 90:467480 .

196. Ohnishi, Y. 1975. F factor promotes turnover of stable RNA in Escherichia coli. Science 187:257-258.

197. Ohno, S. 1970. Evolution by gene duplication. George Allen \& Unwin Ltd, London.

198. Ohta, T. 1973. Slightly deleterious mutant substitutions in evolution. Nature (London) 246:96-98.

199. Ohta, T. 1974. Mutational pressure as the main cause of molecular evolution and polymorphism. Nature (London) 252:351-354.

200. Ohtsubo, E., R. C. Deonier, H. J. Lee, and N. Davidson. 1974. Electron microscope heteroduplex studies of sequence relations among plasmids of Escherichia coli. IV. The F sequences F14. J. Mol. Biol. 89:565-584.

201. Olivera, B. M., and F. Bonhoeffer. 1974. Replication of Escherichia coli requires DNA polymerase 1. Nature (London) 250:513-514.

202. Olsen, R. H., and P. Shipley. 1973. Host range and properties of the Pseudomonas aeruginosa R factor R1822. J. Bacteriol. 113:772780 .

203. Ostertag, W., G. Roesler, C. J. Krieg, J. Kind, T. Cole, T. Crozier, G. Gaedicke, G. Steinheider, N. Kluge, and S. K. Dube. 1974. Induction of endogenous virus and thymidine kinase by bromodeoxyuridine in cell cultures transformed by Friend virus. Proc. Natl. Acad. Sci. U. S. A. 71:4980-4985.

204. Palchoudry, S. R., and V. N. Iyer. 1971. Nonessentiality of the recA- mutation in the phenomenon of bacteriophage M13 induced elimination of $\mathrm{F}^{\mathbf{1}}$ factors. J. Bacteriol. 106:1040-1042.

205. Pandey, K. K. 1972. Origin of genetic recombination: regulation of genetic recombination in the higher organisms - a theory. J. Theor. Appl. Genet. 42:250-261.

206. Parks, W. P., D. M. Livingston, G. J. Todaro, R. E. Benveniste, and E. M. Scolnick. 1973. Radioimmunoassay of mammalian type $\mathrm{C}$ proteins. III. Detection of viral antigen in normal murine cells and tissues. J. Exp. Med. 137:622-635.

207. Ptashne, K., and S. N. Cohen. 1975. Occurrence of insertion (IS) regions on plasmid deoxyribonucleic as direct and inverted nucleotide sequence duplications. J. Bacteriol. 122:776-781.

208. Ravin, A. W. 1974. Microbial transformation, p. 513-516. In A. Laskin and H. Lechavalier (ed.), Handbook of microbiology, vol. IV. CRC Press, Cleveland, Ohio.

209. Reanney, D. C. 1974. Viruses and evolution. Int. Rev. Cytol. 37:21-52.

210. Reanney, D. C. 1974. On the origin of prokar- yotes. J. Theor. Biol. 48:243-251.

211. Reanney, D. C. 1975 . A regulatory role for viral RNA in eukaryotes. J. Theor. Biol. 49:461492

212. Reanney, D. C., and S. C. Marsh. 1973. The ecology of viruses attacking Bacillus stearothermophilus in soil. Soil Biol. Biochem. 5:399-408.

213. Reanney, D. C., and M. Wood. 1973. Phages for facultatively thermophilic strains of Bacillus stearothermophilus; 1-D-5. N.Z. J. Sci. 16:681-695.

214. Reanney, D. C., and C. K. Teh. 1976. Mapping pathways of possible phage-mediated genetic interchange among soil bacilli. Soil Biol. Biochem. 8:305-311.

215. Rees, H., and J. B. Thompson. 1956. Genotypic control of chromosome behaviour in rye. III. Chiasma frequency in homozygotes and heterozygotes. Heredity 10:409-424.

216. Reid, M. S., and R. E. F. Matthews. 1976. On the origin of the mosaic induced by turnip yellow mosaic virus. Virology 28:563-570.

217. Rheinwald, J. C., A. M. Chakrabarty, and I. C. Gunsalus. 1973. A transmissable plasmid controlling camphor oxidation in Pseudomonas putida. Proc. Natl. Acad. Sci. U. S. A. 70:885-889.

218. Richmond, M. H., and P. H. Clarke. 1975. Evolutionary prospects for Pseudomonas species, p. 341-381. In P. Clarke and M. Richmond (ed.), Genetics and biochemistry of Pseudomonas. John Wiley \& Sons, Inc., New York.

219. Richmond, M. H., and B. Wiedeman. 1974.

- Plasmids and bacterial evolution, p. 59-85. In Evolution in the microbial world. Soc. Gen. Microbiol. Symp., vol. 24. Cambridge University Press, Cambridge.

220. Richmond, R. C. 1970 . Non-Darwinian evolution: a critique. Nature (London) 255:10251028.

221. Rigby, P. W. J., B. D. Burleigh, and B. S. Hartley. 1974. Gene duplication in experimental enzyme evolution. Nature (London) 251:200-204.

222. Robbins, P. W., J. M. Keller, A. Wright, and R. L. Berstein. 1965. Enzymatic and kinetic studies on the mechanism of $\mathrm{O}$-antigen conversion by bacteriophage $\mathrm{e}^{15}$. J. Biol. Chem. 240:384-390.

223. Robbins, P. W., and T. Uchida. 1965. Chemical and macromolecular structure of $\mathrm{O}$-antigen from Salmonella anatum strains carrying mutants of bacteriophage $\mathrm{e}^{15}$. J. Biol. Chem. 240:375-383.

224. Romig, W. R. 1968. Infectivity of Bacillus subtilis bacteriophage deoxyribonucleic acids extracted from mature particles and from lysogenic hosts. Bacteriol. Rev. 32:349-357.

225. Russell, R. L., J. N. Abelson, A. Landy, M. L. Gefter, S. Brenner, and J. D. Smith. 1970. Duplicate genes for tyrosine transfer RNA in Escherichia coli. J. Mol. Biol. 47:1-13.

226. Saedler, H., and B. Heiss. 1973. Multiple cop- 
ies of the insertion-DNA sequences IS1 and IS2 in the chromosome of $E$. coli K12. Mol. Gen. Genet. 122:267-277.

227. Saunders, G. F., and L. L. Campbell. 1966. Characterization of a thermophilic bacteriophage for Bacillus stearothermophilus. J. Bacteriol. 91:340-348.

228. Saunders, R. J. 1975. Transposable resistance genes. Nature (London) 258:384.

229. Schwesinger, M. D., and R. P. Novick. 1975. Prophage-dependent plasmid integration in Staphylococcus aureus. J. Bacteriol. 123:724738.

230. Seaman, E., E. Tarmy, and J. Marmur. 1964. Inducible phages of Bacillus subtilis. Biochemistry 3:607-613.

231. Seman, G., B. M. Levy, M. Pangiel, and L. Dmochowski. 1975. Type $C$ virus particles in placenta of the cottontop marmoset ( $\mathrm{Sa}$ guinus oedipus). J. Natl. Cancer Inst. 54:251-252.

232. Semancik, J. S., and L. M. C. Geelan. 1975. Detection of DNA complementary to pathogenic viroid RNA in exocortis disease. $\mathrm{Na}$ ture (London) 256:753-756.

233. Shannon, C. E. 1949. The mathematical theory of communication. In C. E. Shannon and W. Weaver (ed.), The mathematical theory of communication. University of Illinois Press, Urbana, Ill.

234. Sharp, P. A., S. N. Cohen, and N. Davidson. 1973. Electron microscope heteroduplex studies of sequence relations among plasmids of Escherichia coli. II. Structure of drug resistance (R) factors and F factors. J. Mol. Biol. 75:235-255.

235. Signer, E. R. 1968. Lysogeny: the integration problem. Annu. Rev. Microbiol. 22:451-488.

236. Simpson, G. G., C. S. Pittendrigh, and L. H. Tiffany. 1958. Life. Routledge and Kegan Paul, London.

237. Smith, K. M. 1972. A textbook of plant virus diseases. Longman, London.

238. Smith, N. R., R. E. Gordon, and F. E. Clark. 1952. Aerobic spore forming bacteria. In US. Department of Agriculture, Monogr. no. 16. Washington, D.C.

239. Solter, D., W. Biczysko, and H. Koprowski. 1974. Host-virus relationship at the embryonic level, p. 3-30. In E. Kurstak and K. Maramorosch (ed.), Viruses, evolution and cancer. Academic Press Inc., New York.

240. Sprague, G. F., and H. H. McKinney. 1966. Aberrant ratio: an anomaly in maize associated with virus infection. Genetics 54:12871296.

241. Sprague, G. F., and H. H. McKinney. 1971. Further evidence on the genetic behaviour of AR in maize. Genetics 67:533-542.

242. Stanisich, V. A., and M. H. Richmond. 1975. Gene transfer in the genus Pseudomonas, $\mathrm{p}$. 163-190. In P. Clarke and $M$. Richmond (ed.), Genetics and biochemistry of Pseudomonas. John Wiley \& Sons, Inc., New York.

243. Starlinger, P., and H. Saedler. 1972. Insertion mutations in microorganisms. Biochemie
54:177-185.

244. Stehelin, D., H. E. Varmus, J. M. Bishop, and P. K. Vogt. 1976. DNA related to the transforming gene(s) of avian sarcoma virus is present in normal avian DNA. Nature (London) 260:170-173.

245. Stent, G. S. 1963. The molecular biology of bacterial viruses. Freeman \& Co., San Francisco.

246. Stodolsky, M. 1974. Recipient gene duplication during generalised transduction. Genetics 78:809-882.

247. Straus, D. S. 1974. Induction by mutagens of tandem gene duplications in the glyS region of the Escherichia coli chromosome. Genetics 78:823-830.

248. Sykes, R. B., and R. H. Richmond. 1970. Intergeneric transfer of a $\beta$-lactamase gene between $P s$. aeroginosa and $E$. coli. Nature (London) 226:952-954.

249. Szybalski, W., and E. H. Szybalski. 1974. Visualization of the evolution of viral genomes, p. 563-580. In E. Kurstak and K. Maramorosch (ed.), Viruses, evolution and cancer. Academic Press Inc., New York.

250. Taylor, A. L. 1963. Bacteriophage-induced mutation in Escherichia coli. Proc. Natl. Acad. Sci. U. S. A. 50:1043-1051.

251. Temin, H. M. 1974. On the origin of RNA tumor viruses. Annu. Rev. Genet. 8:155-177.

252. Thomas, C. A., and L. A. MacHattie. 1967. The anatomy of viral DNA molecules. Annu. Rev. Biochem. 36:485-518.

253. Thorne, C. B. 1974. Transduction, p. 517-521. In A. Laskin and H. Leehevalier (ed.), Handbook of microbiology, vol. IV. CRC Press, Cleveland, Ohio.

254. Todaro, G. J. 1975. Evolution and modes of transmission of RNA tumor viruses. Am. J. Pathol. 81:590-605.

255. Toyama, S., S. Ikawa, and H. Uetake. 1968. Molecular forms of phage DNA during lysogenisation. Annu. Rep. Inst. Virus. Res. Kyoto Univ. 11:33.

256. Trautner, T. A., M. N. Schwartz, and A. Kornberg. 1962. Enzymatic synthesis of DNA. X. Influence of bromourarcil substitutions on replication. Proc. Natl. Acad. Sci. U. S. A. 48:449-455.

257. Uetake, H. 1964. Bacteriophage-controlled synthesis of somatic antigens in Salmonella. Annu. Rep. Inst. Virus. Res. Kyoto Univ. 7:38-55.

258. Uetake, H., and S. Hagiwara. 1972. Phenotypic mixing as a mechanism of conversion gene transfer. Virology 47:48-53.

259. Vasil, I. K., and V. Vasil. 1972. Totipotency and embryogenesis in plant cell and tissue cultures. In Vitro 8:117-125.

260. Vijer, J. C., M. Van Der, M. Van Es-Boon, and M. F. Michel. 1972. Lysogenic conversion in Staphylococcus aureus to leucocidin production. J. Virol. 10:318-319.

261. Wallace, B., and T. L. Kass. 1974. On the structure of gene control regions. Genetics 77:541-558. 
262. Weiss, R. 1976. Molecular analysis of the oncogene. Nature (London) 260:93.

263. West, D. A. 1971. Does virus infection have evolutionary significance? Nature (London) 229:637.

264. Wilson, A. C., L. R. Maxson, and V. M. Sarich. 1974. Two types of molecular evolution: evidence from studies of interspecific hybridisation. Proc. Natl. Acad. Sci. U. S. A. 71: 2843-2847.

265. Wilson, D. A., and C. A. Thomas, Jr. 1974. Palindromes in chromosomes. J. Mol. Biol. 84:115-144.

266. Winocour, E. 1969. Some aspects of the interaction between polyoma virus and cell DNA. Adv. Virus Res. 14:153-200.

267. Wiseman, R. L., J. M. Bowes, and A.K. Dunker. 1974. Bacterial viruses containing single-stranded nucleic acid, p. 617-628. In A. Laskin and H. Lechevalier (ed.), Handbook of microbiology, vol. I. CRC Press, Ohio.

268. Wong-Staal, F., R. C. Gallo, and D. Gillespie.
1975. Genetic relationship of a primate RNA tumour virus genome to genes in normal mice. Nature (London) 256:670-672.

269. Wright, A. 1971 . Mechanism of conversion of the Salmonella $\mathrm{O}$-antigens by bacteriophage $\mathrm{e}^{34}$. J. Bacteriol. 105:927-936.

270. Yoshiki, T., R. C. Mellors, and W. D. Hardy, Jr. 1973. Common cell-surface antigen associated with murine and feline C-type RNA leukemia viruses. Proc. Natl. Adad. Sci. U.S.A. 70:1878-1882.

271. Yourna, J., T. Kohno, and R. Roth. 1970. Enzyme evolution: generation of a bifunctional enzyme by fusion of adjacent genes. Nature (London) 228:820-824.

272. Zarachi, Y., G. Simpchen, J. Hillel, and T. Schaap. 1972. Chiasmata and the breeding system in wild populations of diploid wheats. Chromosoma 38:77-94.

273. Zhdanov, V. M., and T. I. Tikchonenko. 1974. Viruses as a factor of evolution: exchange of genetic information in the biosphere. Adv. Virus Res. 19:361-395. 